\title{
Cross-cultural adaptation of the Examination of Anomalous World Experiences into Portuguese
}

\author{
Luís Madeira $^{1,2}$, Adrian Spremberg ${ }^{3}$, Guilherme Queiroz ${ }^{4}$, João da Eira ${ }^{5}$, \\ Teresa Filipe ${ }^{2,6}$, Mariana Melo ${ }^{2,6}$, Guilherme Messas ${ }^{7}$, Maria Luísa Figueira ${ }^{2}$, \\ Elizabeth Pienkos ${ }^{8}$, Louis Sass ${ }^{9}$
}

\footnotetext{
${ }^{1}$ Centro Hospitalar Lisboa Norte, Psychiatry Department, Lisbon, Portugal

${ }^{2}$ Faculdade de Medicina, Universidade de Lisboa, Lisbon, Portugal

${ }^{3}$ University of Campinas (Unicamp), Department of Psychiatry, Brazil

${ }^{4}$ Faculdade de Medicina, Universidade de Coimbra, Coimbra, Portugal

${ }^{5}$ Faculdade de Medicina, Universidade de Porto, Porto, Portugal

${ }^{6}$ Centro Hospitalar Psiquiátrico de Lisboa, Lisboa, Portugal

${ }^{7}$ Faculdade de Ciências Médicas da Santa Casa de São Paulo, São Paulo, Brazil

${ }^{8}$ Psychology Department, Clarkson University, Potsdam, NY, USA

${ }^{9}$ Graduate School of Applied and Professional Psychology, Rutgers University, Piscataway, New Jersey, USA
}

\section{Corresponding Author:}

Luís António Proença Duarte Madeira

E-mail: luismadeiramd@gmail.com

Address: Faculdade de Medicina - Universidade de Lisboa

$$
\text { Av. Prof. Egas Moniz, 1649-035 Lisboa }
$$

Telephone: 00351963341571

All authors declare no conflict of interests. 


\begin{abstract}
Until the present moment, there have been no validated instruments for a systematic assessment of anomalous world experiences in Portuguese. The Examination of Anomalous World Experiences (EAWE) is an interview designed to investigate such experiences. Our study was intended to perform a cross-cultural adaptation of the Examination of Anomalous World Experiences (EAWE) into Portuguese. Our findings suggest that the Portuguese version of the EAWE could be used for researching anomalous subjectivity in mental disorders in the Portuguese-speaking population.
\end{abstract}

Keywords: Psychopathology, subjectivity, world-experiences, schizophrenia 


\section{Introduction}

Anomalous world experiences (AWEs) are assorted changes in the lived world and have been described in various mental disorders and particularly in the schizophrenia spectrum (SS). They appear as disturbances of subjectivity alongside anomalous selfexperiences (ASEs). ASEs have already been systematically explored in the SS by the use of the Examination of Anomalous Self Experience (EASE) interview. The Examination of Anomalous World Experience (EAWE) was recently published to research AWEs. Our cross-cultural adaptation aims to introduce the EAWE into clinical practice and research in Portugal, specifically regarding the study of subjects within the schizophrenia spectrum.

According to the self-disorders model of schizophrenia, both AWEs and ASEs are considered to be manifestations of disturbed ipseity. Disturbances of self-experience (thought, self, body, existence) and world-experience (space, time, language, others, atmosphere and existence) seem to be closely intertwined - in that they both involve the same disturbances of basic or minimal self-awareness that are considered to underlie this disorder. The EASE and EAWE allow a systematic exploration of forms of increased self-reflexivity, forms of disturbed grip or hold on reality, and forms of diminished intensity or vitality of the subjects' self-presence or the inhabited world. The extensive use of the EASE in persons with schizophrenia [7], in those with schizotypic and schizotaxic traits [9], in first episode psychosis [8,10], and in prodromal phases of schizophrenia [11,12] [13] [14] has identified that ASEs are specific to these samples. Indeed, the self-disorder model of schizophrenia is now substantiated by conceptual [15,16], clinical [17], and neurobiological evidence [14,18] [16] [19].

Anomalous world experiences encompass modes of experiencing space and objects, time and events, interpersonal features of other persons, properties of language, the whole "sense" of immersion in a setting or atmosphere, and attitudes or viewpoints towards existence or reality as a whole (existential orientation). The EAWE is an instrument consisting of a comprehensive and richly detailed set of items and subtypes of qualitative abnormalities of the "lived world". These subtle changes of reality contact appear to provide deep insight into the texture and structure of subjectivity in mental disorders and allow the segregation of new phenomena under these umbrella terms. 
Anomalous world experiences permit a revised and fuller understanding of psychiatric categories and an increase in the validity and reliability of their assessment.

Despite the fact that changes in the lived world are also considered distinctive of patients with schizophrenia in clinical and psychopathological descriptions, both classic and contemporary, they have not yet been thoroughly explored. Until recently there has been no instrument that explores how time, space, the surrounding atmosphere, language, other persons and the existential mindset of patients can be transformed. The full set of items in the EAWE systematically addresses disturbances of implicit and tacit world engagement and understanding.

\section{Methods}

\section{Clinical Measure}

Examination of Anomalous World Experiences $\{$ Sass:2017dd

This is a semi-structured interview for anomalous subjective experience that includes 70 items (205 subtypes) and a Cronbach $\alpha$ over 0.82 with high inter-rater reliability for both EAWE total scores $(\rho>0.83$; average $\kappa$ values were at least 0.78 for each study) and EAWE domain-specific scores ( $\kappa$ not lower than 0.73 ). It is divided into six domains: a) 17 items (45 subtypes) in the Space and objects domain; b) 6 items (26 subtypes) in the Time and events domain; c) 14 items (46 subtypes) in the Other persons domain; d) 10 items (29 subtypes) in the Language domain; e) 12 items (43 subtypes) in the Atmosphere domain and (f) 11 items (16 subtypes) in the Existential orientation domain. Items are scored dichotomously according to presence (1) or absence (0) of items. Our use of the EAWE and the EASE includes the examination of items (and subtypes), as increased phenomenological detail appears necessary to develop a thorough understanding of the subjective world in psychosis.

\section{Cross-cultural adaptation}

The cross-cultural adaptation process was based on the standardized procedures \{Beaton:2000fj\}. Formal authorization was obtained from the authors to adapt the instrument to European Portuguese. We carried out initial synthesis and back translation after which a committee of judges considered a final version that was submitted to the authors of the EAWE. 


\section{Initial translation}

We asked four independent translators ( $11, \mathrm{~T} 2, \mathrm{~T} 3$ and $\mathrm{T} 4)$ to perform a translation of the English version into Portuguese. $\mathrm{T} 1$ is an experienced psychiatrist $(\mathrm{MD}, \mathrm{PhD})$ familiar with the constructs of the instruments. T2 and T3 were chosen in order to minimize influence of psychiatric jargon and were medical students. T3 is a Brazilian Psychologist and was chosen in order to minimize differences between European and Brazilian Portuguese and, when necessary, to provide terms in both dialects. The initial translation involved translating and formatting the full EAWE paper - including introduction, items and subtypes, and examples aiming to maintain operational equivalence of the items of the initial English version of the EAWE. The introduction of the EAWE is particularly relevant as it focuses on theoretical considerations, the development of the interview, and the general guidelines to perform the interview - all of which seemed essential to using the phenomenologically based interview.

\section{Synthesis of the Translation}

The four translators combined the three versions of the translation into a single version, with help by an additional observer.

\section{Back translation}

The version obtained through synthesis was given to a medical doctor knowledgeable about phenomenology who was blind to the original instrument. The version was sent to the original authors for suggestions and approval.

\section{Committee of judges}

We asked a committee to evaluate the original version versus the European Portuguese version of the EAWE. Four psychiatrists were involved. They provided feedback on (1) its content, focusing on the quality of the translation of words (semantic features), (2) the appropriate use of colloquialisms and linguistic expressions (idiomatic features), (3) the concept of the phenomenon to be assessed (conceptual features), and (4) adaptation to the target population's daily life (experiential equivalence). After the suggestions of the committee, a new synthetic version in Portuguese was proposed. 
Pretest of the final version

24 participants with the diagnosis of non-affective first episode psychosis according to the DSM-5 \{Association:2013vi\} completed the final version to verify its comprehension by a possible target population. The instrument was easily administered and comprehended with no reported difficulties.

Submission to the author of the original instrument

The back translation of the final Portuguese version was submitted to the author of the original instrument to ensure that the adapted version was compatible with the original one. 


\section{Examinação $^{10}$ das Anomalias na Experiência do Mundo}

\section{Resumo}

A EAWE, Examinação das Anomalias na Experiência do Mundo, é uma entrevista semiestruturada que tem por objetivo permitir a descrição e discussão de vários aspectos ${ }^{11}$ da experiência de cada pessoa do seu mundo vivido. Este instrumento baseia-se na tradição da psicopatologia fenomenológica e pretende explorar, de uma forma qualitativamente rica, 6 dimensões da subjetividade - nomeadamente, a experiência (1) do Espaço e objetos, (2) do Tempo e eventos, (3) das Outras pessoas, (4) da Linguagem (quer escrita quer falada), (5) da Atmosfera, (sentido geral de realidade, familiaridade, vitalidade, significado e relevância), e (6) da Orientação Existencial (valores, atitudes e opiniões sobre o mundo).

A EAWE tem por base, e direciona-se primariamente para, as experiências que consideradas comuns, e por vezes distintivas, em perturbações do espectro da esquizofrenia. Por outro lado, pode também ser usada para investigar perturbações da experiência do mundo em outras populações. Após uma introdução teórica e metodológica, a EAWE lista 75 itens específicos, muitas vezes seguidos de subtipos, em 6 domínios, em conjunto com citações ilustrativas de pacientes.

A EAWE aparece em um volume especial da revista Psychopathology que contém também um prefácio com orientações (em que se reconhece a dificuldade e a necessidade de estudar a vida subjetiva), bem como um relatório breve sobre a sua fiabilidade. Além disso, são incluídos 6 artigos auxiliares e seminais, que percorrem a teoria, a investigação e a sabedoria clínica relevantes para os 6 domínios experienciais.

Palavras-chave: psicopatologia; subjetividade; experiências de mundo; esquizofrenia.

\footnotetext{
${ }^{10} \mathrm{Na}$ variação linguística brasileira, é mais comum o uso do termo "Exame".

${ }^{11}$ Para esta edição, optamos pela grafia utilizada na variação linguística brasileira do termo "aspecto".
} 


\section{Introdução}

A Examinação das Anomalias na Experiência do Mundo (Examination of Anomalous World Experiences) é uma entrevista semiestruturada construída para explorar anomalias da experiência subjetiva que uma pessoa tem do seu mundo externo, da sua linguagem e das outras pessoas, isto é, do seu "mundo vivido". Baseia-se primariamente, embora não exclusivamente, em descrições experienciais de indivíduos com Perturbação do Espectro da Esquizofrenia, além de descrições obtidas na prática clínica sobre estes indivíduos. Nesse sentido, pode ter significativa relevância do ponto de vista descritivo, diferencial, diagnóstico e, talvez, também prognóstico para estas e outras doenças. Esta apresentação contém: 1) uma introdução que trata de questões teóricas e práticas; 2) a sequência de itens da EAWE que inclui os seus seis domínios de experiências (Espaço e objetos; Tempo e eventos; Outras Pessoas; Linguagem; Atmosfera; e Orientação existencial); e 3) o Apêndice A: uma listagem de todos os itens da EAWE e seus subtipos para utilização durante a entrevista, formatada para ser usada como folha de cotação; e o Apêndice B: uma lista que compara os itens da EAWE com os itens semelhantes da EASE (Examinação das experiências anômalas do eu) e os da BASBS ou escala de Bonn (Bonner Skala für die Beurteilung von Basissymptomen). Ambos estão disponíveis online como material suplementar. ${ }^{12}$

\section{Finalidades e Considerações teóricas}

As perturbações do "mundo vivido" - incluindo as perturbações da experiência do espaço e objetos, tempo e eventos, outras pessoas, linguagem, atmosfera e atitude para com a existência - têm sido reconhecidas como características importantes das Perturbações do Espectro da Esquizofrenia. São proeminentes em descrições autobiográficas e em relatos na primeira pessoa, bem como em descrições provenientes da anamnese e do exame psicopatológico em textos clássicos e contemporâneos. Algumas dessas anomalias já tinham sido identificadas e descritas na BSABS [1]. No entanto, as anomalias em questão não tinham sido organizadas e compiladas numa lista sinóptica única que fosse simultaneamente abrangente e detalhada para o propósito de uma exploração empírico-fenomenológica das anomalias qualitativas do mundo vivido.

\footnotetext{
12 Os apêndices não estão traduzidos para o português e estão disponíveis como arquivos separados, em links no site da revista.
} 
A EAWE (pronunciada /iiiuiiii/) focaliza-se primariamente nas anomalias experienciais comuns no espectro da esquizofrenia (embora não necessariamente exclusivo desta) podendo, porém, ser utilizada para explorar várias perturbações. A EAWE não se focaliza nos sintomas floridos e mais evidentes, cruciais para o atual padrão diagnóstico (tais como delírios, alucinações e sintomas "negativos"), mas em avaliar a orientação ou vulnerabilidade subjacentes, manifestas em alterações subtis na experiência ou na perspectiva subjetiva da pessoa sobre o seu mundo vivido. Em conjunto, os seis domínios do EAWE destinam-se a cobrir todos os principais domínios da experiência do mundo.

Embora seja provável que tenha algum significado diagnóstico, a EAWE não se destina a ser usada individualmente como instrumento de diagnóstico; os sintomas e características experienciais em que se concentra estão na sua maioria ausentes ou então são periféricos nos sistemas de diagnóstico padrão, tais como DSM (Manual Diagnóstico e Estatístico de Transtornos Mentais) e CID (Classificação Internacional de Doenças) (embora talvez seja relevante para um futuro sistema, mais fenomenológico). A entrevista pode ser usada para uma avaliação, fornecendo insights sobre a textura, estrutura e aspectos da dinâmica da vida subjetiva, bem como para desenvolver e comunicar uma compreensão mais profunda da doença do indivíduo e da sua perspectiva pessoal sobre a mesma - tornando-se assim potencialmente útil na psicoterapia e para outras finalidades clínicas.

O EAWE é um complemento da EASE [2], uma entrevista semiestruturada e fenomenologicamente orientada que incide sobre as perturbações da consciência básica, mínima ou fundamental do self ("ipseity"). A EAWE foi desenvolvida para identificar quais aspectos na esquizofrenia se reportam mais diretamente à experiência e orientação para o mundo externo. A experiência do Eu e a experiência de mundo estão, porém, fortemente interligadas e assim, por vezes sobrepõem-se: praticamente todos os fenomenologistas enfatizaram a relação íntima entre os aspectos ou polos subjetivos e objetivos dos atos de consciência (para uma discussão mais aprofundada, veja Sass et al [3]). Desta forma, as distorções de "ipseity" ou experiência básica do "eu" parecem correlacionadas e interligadas a um afrouxamento ou outra qualquer perturbação da capacidade do sujeito de "apreender", “compreender" ou "segurar" o mundo. [4, 5].

Neste sentido, não são possíveis distinções absolutas e, de fato, a distinção entre a EASE e a EAWE é necessariamente arbitrária. Consideremos os domínios do tempo, 
outras pessoas, e linguagem (Domínios 2, 3, 4) da EAWE. O tempo é, obviamente, uma dimensão básica da experiência do mundo; no entanto, a temporalidade básica ou implícita [6], que William James [7] denominou de "specious present", é também em si o meio das experiências básicas do Self. A consciência dos outros e das suas subjetividades está ligada à consciência de si mesmo. A linguagem deriva (como um sistema) e chega (como o discurso ou a escrita dos outros) do mundo social, ainda que também seja incorporada por e sobre o sujeito; só assim conseguimos enquadrar a nossa experiência dos objetos externos e dos eventos.

É razoável, portanto, esperar que certos itens da EASE sejam relevantes para os domínios avaliados na EAWE. Os itens da EASE que pertencem diretamente à experiência do mundo estão, assim, também incluídos na EAWE, particularmente aqueles encontrados no Domínio EASE 6: Reorientação Existencial. Os números dos itens da EASE (e da escala de Bonn) estão assinalados quando usados na EAWE, e uma tabela completa com todas as semelhanças e sobreposições com a EASE e a Escala de Bonn está disponível como material online suplementar (Apêndice B).

Adicionalmente, as modificações de experiência do mundo (como as transformações da "ipseity" ou experiência básica do Self) têm normalmente um carácter global ou holístico que desafia a operacionalização pré-determinada em fatores ou características distintivas. O tempo e espaço, por exemplo, não são características independentes da nossa experiência, mas dimensões interdependentes ou formas de experiência que variam conjuntamente com determinados modos [8]. Além disso, a nossa experiência do espaço e do mundo objetivo está tipicamente imbuída de uma percepção implícita da presença de outros seres conscientes (o domínio Outras Pessoas), potenciais espectadores com outros ângulos de ver o mundo [9]. As qualidades atmosféricas ou penetrantes (semelhantes aos estados de humor) são particularmente difíceis de capturar, descritas metaforicamente por um participante como o "odor" de uma experiência. Nenhum destes factos ${ }^{13}$ deve, no entanto, ser aceito como justificativa para se reduzir o interesse humanístico ou a relevância científica do domínio de experienciação subjetiva.

Nós reconhecemos por princípio que seria impossível produzir um sistema de classificação operacional que faça plena justiça à complexidade do fluxo da experiência vivida. Os itens listados na EAWE são uma tentativa de encontrar um equilíbrio entre as

\footnotetext{
${ }^{13} \mathrm{Na}$ variedade linguística brasileira, a grafia mais comum do termo é "fatos".
} 
necessidades de operacionalização e a tentativa de capturar aspectos holísticos, muitas vezes elusivos, das alterações experienciais em questão. Dessa forma, os itens individuais da EAWE não devem ser concebidos como descritores de sintomas distintos que ocorrem independentes uns dos outros. Frequentemente, vários itens da EAWE podem corresponder a uma única mutação estrutural da experiência, considerada a partir de diferentes pontos de vista ou ângulos (por exemplo, o seu aspecto espacial, o seu aspecto temporal, etc.). A estrutura da EAWE reflete, portanto, vários elementos teóricos, práticos e experienciais (por vezes em conflito). Tanto quanto possível, notas são fornecidas no texto para guiar o entrevistador a outros itens da EAWE que são estruturalmente semelhantes ou que coocorrem frequentemente com o item ou subitem em questão.

\section{Desenvolvimento da EAWE}

Os itens da EAWE derivam de relatos clínico-fenomenológicos ou descrições na primeira pessoa retiradas da literatura em Psicopatologia sobre a esquizofrenia e perturbações a ela relacionadas e, ocasionalmente, a partir de experiências da prática clínica dos autores. Os itens foram aperfeiçoados por meio de entrevistas-testes que usaram várias versões da EAWE, e também por meio de conversas e correspondências com pessoas com esquizofrenia ou outras psicoses. Baseando-se no feedback dos indivíduos entrevistados e nos dados das correspondências, os autores fizeram diversas revisões e adições para melhorar a clareza, a facilidade de uso e a profundidade da entrevista.

Estamos essencialmente em dívida com a Escala de Bonn e a EASE; alguns dos nossos itens derivaram diretamente destas escalas. Estes itens estão indicados com as iniciais "BS" e "EASE" seguidos do item correspondente na escala apropriada. Outros itens refletem aspectos da experiência que são semelhantes, embora não idênticos, a itens da escala de Bonn ou da EASE. Itens idênticos ou quase idênticos estão indicados com um sinal "="; aqueles que são parcialmente semelhantes, ou em que existe uma sobreposição parcial, estão indicados com um sinal “ " (ver Apêndice B, que mostra estas semelhanças com a EASE e escala de Bonn, e que está incluído como material suplementar). Além de se basear nestes dois instrumentos, os itens da EAWE e as suas descrições baseiam-se na fenomenologia (particularmente nos filósofos Husserl, Heidegger, Merleau-Ponty, e nos psiquiatras Minkowski, Conrad e Blankenburg) e também em estudos clássicos e contemporâneos em Psicopatologia. Referências 
bibliográficas foram providenciadas para as descrições exatas (exceto quando as descrições são de sujeitos de investigação ou dos pacientes, que aparecem listados como “dados não publicados") que são apresentadas como exemplos e ocasionalmente dentro da descrição do item ou do subtipo.

\section{Itens ou subtipos auxiliares}

Alguns dos itens e subtipos da EAWE foram incluídos apesar de não serem mais comuns nas perturbações do espectro da esquizofrenia do que em outras perturbações, especialmente Perturbações Afetivas graves e certas formas de Perturbação Delirante Crónica. Estas são incluídas pois (1) são frequentemente encontradas no espectro da esquizofrenia, (2) ajudam a completar a lógica do sistema da EAWE e (3) podem ser importantes em estudos comparativos. Esses itens e subtipos estão indicados com um asterisco ("estrela") em frente à denominação do subtipo/item. Alguns dos itens com estrela podem também representar experiências que possam ter uma variante específica para a esquizofrenia, mas cujo caráter distintivo seja difícil de identificar, exigindo maior detalhe.

Os desafios na definição e atribuição de status nosológico aos sinais e sintomas psiquiátricos são característicos da psiquiatria moderna, talvez mais especialmente no caso particular da esquizofrenia. Aqui, não adotamos uma posição específica sobre o significado diagnóstico de quaisquer dos itens da EAWE. Os asteriscos simplesmente registam a nossa melhor interpretação (numa versão simplificada e/ou) sobre o que, de acordo com a literatura psicopatológica clássica, seria ou não considerado distintivo de esquizofrenia (ou do espectro da esquizofrenia), contrastando com outras "psicoses funcionais" (formas graves de perturbação depressiva major, perturbação bipolar ou perturbação delirante). Na verdade, um uso potencial da EAWE será estabelecer quais formas de experiência no mundo são, de facto, mais discriminativas do espectro da esquizofrenia quando comparado com outras perturbações. Alguns conjuntos de itens da EAWE, ou algumas ponderações sobre estes, podem vir a tornar-se úteis para estudos preditivos ou para diagnóstico diferencial. Também não devemos assumir, claramente, que tenha de existir uma forma apenas em que esteja alterada a experiência do mundo na esquizofrenia e outras condições; é possível que os modos possíveis ou mutações da experiência do mundo na esquizofrenia sejam heterogêneos, ou talvez até interrelacionados. 
Alguns exemplos dos itens com estrela ou subtipos são: 1.8.7, Experiência afetiva do espaço*; 2.1.1, O tempo ou os movimentos parecem acelerados*; 3.4.1, Sentimento de insegurança própria, juízo crítico de si mesmo *; 5.15.1, União mística com o mundo*; e 6.6 Responsabilidade ou culpa impossíveis*. Embora estas experiências devam ser avaliadas como qualquer outro item ou subtipo, podem precisar de um tratamento separado na análise de dados.

\section{Orientações gerais para a realização da entrevista}

\section{Dificuldades intrínsecas da entrevista}

Em geral, a EAWE tem por objetivo captar experiências que o sujeito irá reconhecer como anômalas, no sentido em que diferem do que este considera a experiência normal da maioria das outras pessoas ou acredita ser característico da sua própria experiência em uma situação mais habitual/normal. As experiências subjetivas descritas na EAWE são muitas vezes estranhas, privadas, fugazes; e muitas irão, portanto, ter uma qualidade inerentemente inefável, o que torna desafiador o trabalho de questionar sobre elas e descrevê-las. Algumas experiências podem inclusive prejudicar a capacidade de comunicação linguística. Além disso, as descrições da experiência subjetiva estão sujeitas a várias formas de distorção e não devem ser tomadas simplesmente pelo seu valor facial; portanto, é necessário que tanto o entrevistador quanto o entrevistado tenham capacidade de, e o interesse em, examinarem em conjunto as experiências relatadas.

Também é importante ter em conta o papel da metáfora, uma característica indispensável da linguagem, frequentemente usada para descrever experiências que são especialmente subtis $^{14}$, pervasivas ou incomuns. A metáfora, no entanto, pode ser tão reveladora como enganadora, e assim é necessária consciência crítica para determinar se a descrição do sujeito preenche os critérios de um item ou subtipo.

\section{Pré-requisitos}

O tom da entrevista é crucial. A experiência mostrou que pacientes e participantes em estudos se sentem mais tranquilos ao encontrar um entrevistador interessado em (e familiarizado com) experiências subtis e muitas vezes desconcertantes, que podem nunca ter divulgado ou discutido com outras pessoas. Mas também é possível que o participante

14 “sutis", na variedade linguística brasileira. 
sinta que aspectos íntimos da sua vida privada estão a ser invadidos, ou que esteja relutante ou embaraçado em falar de fenómenos que lhe possam ser íntimos ou estranhos, e que não são partilhados na vida do dia-a-dia ou sequer em contexto duma consulta de Psiquiatria. É assim importante oferecer um sentimento dum diálogo caloroso, neutro e sem juízos de valor, desprovido de curiosidade meramente voyeurística ou de objetificação.

Para ser capaz de escutar de forma sensível e informada, o entrevistador precisa de uma compreensão básica quer da psicopatologia geral quer dos aspectos fenomenológicos da consciência humana e da psicopatologia. Vários textos fundamentais da psicopatologia fenomenológica aparecem nas referências deste documento. Uma discussão específica dos domínios da EAWE (e referências relevantes) pode ser encontrada em três artigos de Sass e Pienkos e também numa série de outros artigos seminais dedicados a cada um dos seis domínios da EAWE (ver estas referências em [3]).

Geralmente não se deve tentar entrevistar pessoas em fases agudas da doença ou quando estão claramente psicóticas; é necessário algum grau de estabilidade e melhoria clínica para se conseguir o tipo de diálogo que se pretende com a EAWE. Além disso, algumas pessoas com uma história longa de esquizofrenia ou outra doença mental podem não desejar ou ser incapazes de iniciar uma conversa detalhada ou reflexiva sobre as suas experiências, possivelmente devido a episódios psicóticos repetidos ou efeitos secundários da medicação. Alguns indivíduos podem também considerar difícil lembrar das mudanças subtis aqui questionadas, que podem ter precedido ou acompanhado o seu primeiro episódio.

\section{Condução da Entrevista}

O formato semiestruturado da entrevista indica que a interação deve ser sentida como uma conversa mútua e exploratória e não como um interrogatório dirigido. $\mathrm{O}$ objetivo é discernir padrões de experiência a partir de descrições de si mesmo e desvendar as características qualitativas das experiências iluminando-as por meio de descrições vívidas. Assim, o objetivo não é quantificar ou encontrar explicações causais. A entrevista deve seguir o princípio fenomenológico "epoché", "pôr o mundo entre parêntesis" (para uma discussão mais aprofundada, ver Sass et al. [3]), ou seja, deve evitar questões que visem saber se uma experiência é verídica ou não, ou qual o mecanismo ou teoria (por exemplo, neurocognitivo ou psicodinâmica) que a pode explicar, a não ser na medida em 
que estes aspectos façam parte da própria experiência original. (O Domínio 6, Orientação Existencial, é considerado uma exceção, uma vez que se pergunta explicitamente sobre atitudes ou interpretações da experiência ou do mundo). Se o sujeito se expressa nestas formas discutidas, o entrevistador deve focalizar a conversação para "as coisas em si mesmas" no sentido de como o mundo se apresenta ao sujeito; isso pode significar pedir ao sujeito para indicar ou descrever exemplos da experiência em questão e explorar o máximo possível desse instante específico.

É importante que o entrevistador tenha uma sólida compreensão dos fenômenos abordados pela EAWE. Isso permite que as perguntas exploratórias sejam colocadas de uma forma tão simples quanto possível, nas palavras do entrevistador, evitando um tom excessivamente intelectualizado. Para facilitar as entrevistas apresentam-se frases cruciais em itálico. Olhando para estas frases em itálico e em letras capitais, o entrevistador pode lembrar-se (se já está familiarizado com a EAWE) da essência de cada item ou seu subtipo. Em geral, a conversação deve constituir um processo interativo de reflexão mútua no qual o entrevistador e o entrevistado participam em conjunto no processo, muitas vezes difícil, de destilação e esclarecimento das declarações do sujeito. No início da entrevista, é geralmente útil dizer ao sujeito que não se espera que ele tenha tido todas as experiências sobre as quais será questionado; mas também que, se uma determinada descrição ressoar com sendo uma experiência particular, essa experiência deve ser mencionada durante a entrevista.

Para entender melhor a qualidade subjetiva da experiência, é normalmente facilitador perguntar por um ou mais exemplos de um fenômeno específico que esteja a ser questionado (se ainda não foram partilhados espontaneamente), e então inquirir sobre os diversos aspectos e características de um dado incidente com o maior detalhe possível já que é necessário atingir uma compreensão razoável de como foi experienciado. (Para aqueles sujeitos que partilham vários itens, isso pode significar aumentar o tempo da entrevista e pode ser útil dividir a entrevista em várias sessões).

\section{Período a que diz respeito a entrevista}

A EAWE enfatiza experiências pré ou sub-psicóticas, mas isso não significa que devam ser excluídas todas as experiências psicóticas. Alguns fenômenos psicóticos (isto é, experiências claramente separadas da realidade consensual como as alucinações e delírios) estão também incluídas na EAWE, já que estas podem ocorrer e/ou continuar 
fora de um episódio psicótico agudo e podem ser importantes para compreender a qualidade do mundo vivido de cada pessoa (e também, tal como a maioria das distinções, a diferença entre "subpsicótico" e psicótico nem sempre é clara: veja o item 3.7 Perturbações da demarcação Eu-outro). Os investigadores podem desejar considerar se devem ou não incluir e cotar experiências que ocorrem apenas durante um episódio psicótico; se estas forem incluídas, devem ser referidas dessa forma. De forma semelhante, as experiências que ocorrem apenas durante a infância (antes de qualquer período prodrómico) não devem ser desconsideradas, e sim registradas como tal pelo entrevistador ou cotador. As experiências que ocorrem sob efeito de substâncias (excluindo-se fármacos ou terapêuticas psiquiátricas) ou na doença física devem ser excluídas.

Os itens da EAWE podem ser aplicados a vários períodos de tempo dependendo dos objetivos e finalidades do estudo a ser conduzido (ver o início do Domínio 6 para algumas questões (não necessárias) sobre o horizonte temporal). Considera-se prática comum avaliar estas experiências ao longo da vida toda (como é costume na EASE). A avaliação pode, porém, focalizar-se em 14 dias, 4 meses, 1 ano ou outros períodos.

\section{Domínio e Sequência dos Itens}

Antes de iniciar a EAWE, é normalmente útil perguntar a quem será entrevistado sobre a sua experiência de estar doente, incluindo hospitalizações no passado e períodos de maior dificuldade, bem como estabelecer uma discussão aberta sobre o que parece ser mais importante na experiência da doença, particularmente considerando a experiência do mundo externo e das outras pessoas. Isto permite criar um diálogo e proporciona um sentido geral e uma compreensão de quem é entrevistado, enquanto oferece informação ou exemplos relacionados com itens específicos que serão abordados mais tarde na entrevista. Também é possível começar perguntando sobre a história de vida do paciente, e daí focalizar-se em experiências relevantes que possam ser mencionadas. A decisão de por onde começar na EAWE deve ser determinada de acordo com o contexto do decorrer da conversa. No geral, é melhor começar com questões sobre fenômenos que são mais neutros e menos ameaçadores, e depois mover para domínios mais difíceis ou provocadores.

Se não houver razão contextual para começar por outro assunto, é apropriado começar pelo Domínio 1 e só depois mover-se progressivamente por meio das sequências 
para os Domínios 5 e 6. No entanto, entrevistadores interessados num domínio ou em domínios particulares, podem selecionar apenas a secção ou secções mais relevantes. $\mathrm{Na}$ medida do possível, toda a informação relevante referindo-se a um item particular deve ser colecionada antes de passar ao item seguinte. Ao longo da entrevista, o entrevistador deve estar consciente de que cada vez mais itens podem já ter sido avaliados e não necessitam de avaliação separada. Embora seja importante que cada um dos itens seja explorado, não é então necessário que se siga a ordem listada; o fluxo natural da conversa irá frequentemente levar a aspectos anteriores ou posteriores na lista dos itens.

A forma apropriada de introduzir cada um dos domínios é perguntar ao sujeito a questão geral, por exemplo, no Domínio 3: “Já algum dia sentiu mudanças na forma como experiencia outras pessoas?" (O Domínio 1, Espaço e Objetos, pode ser dividido em várias áreas da percepção com questões gerais sobre a visão, espaço, audição etc., usadas para introduzir partes relevantes do domínio). Qualquer coisa importante que o sujeito diga em resposta pode ser então perguntada em maior profundidade, inquirindo sobre detalhes e exemplos que capturem com a maior precisão as descrições do mesmo. Se o entrevistador parecer razoavelmente confiante que um item inteiro não seja aplicável pode não ser necessário investigar subtipos individuais. Porém, se o entrevistador estiver incerto, estes subtipos oferecem estímulos e um meio de explorar as experiências associadas a este item.

Deve-se considerar, entretanto, que o referido pelo entrevistado pode ter de ser categorizado como mais de um item ou mais de um subtipo. Por exemplo, uma fala como “os objetos são artifícios de palco, colocados aqui e ali, cubos geométricos sem qualquer significado" deve ser cotada como 5.2, Perda das Affordances e 5.1.5 Perda da qualidade instigante/estimulante ("cubos sem qualquer significado"), 5.1.4 Falsidade ("artifícios de palco"). Os subtipos estão colocados em conjunto (dentro de um item em particular) por razões descritivas; não existe um pressuposto a priori de que os subtipos partilhem necessariamente de uma essência psicopatológica ou patogenética comum.

Geralmente a EAWE demora 1,5 a 2,5 horas para ser completada, embora a duração da entrevista varie consideravelmente dependendo do entrevistado.

\section{Cotação}

Ao cotar a EAWE, o entrevistador ou o aquele que fizer a cotação (se diferentes) deve marcar itens como $0=$ se definitivamente não presente, $2=$ se definitivamente 
presente, 1 = se tiver dúvida se está presente. Os itens ou subtipos que não forem questionados devem ser deixados em branco. Quem fizer a cotação pode ser incapaz de cotar um determinado subtipo para um dado item, tanto porque nenhum subtipo se aplique ou porque não exista informação suficiente para determinar qual subtipo se deva aplicar. Neste caso, deve ser cotado o item sem indicar o subtipo. O entrevistador (ou quem fizer a cotação) pode ou não fazer notar a razão pela qual nenhum subtipo foi cotado; embora não seja um requisito, tal registro pode ser útil dependendo dos objetivos do estudo.

A magnitude global da pontuação da EAWE (excluindo os itens com asterisco; ver acima) presumidamente deverá refletir a gravidade e abrangência de alterações da experiência do mundo distintivamente semelhantes à esquizofrenia. Dependendo dos objetivos do estudo, os entrevistadores podem desejar calcular o somatório de todos os subtipos ou apenas dos itens. A informação sobre a importância diferencial de itens individuais e subtipos emergirá provavelmente em investigação futura. Como referido acima, se um participante referir um item ou subtipo, mas a experiência só ocorreu durante um período de consumo de drogas ou doença física, o item ou o subtipo não devem ser cotados.

\section{Treino}

O Treino na utilização da EASE e/ou EAWE é muito útil para desenvolver um entendimento das nuances e praticalidades de ambas a EASE e a EAWE e para melhorar a fiabilidade intercotadores. No momento desta publicação, um treino formal na EASE está disponível na Dinamarca (para conhecer os Workshops EASE e materiais relevantes, ver www.easenet.dk); para o treino e consulta os investigadores e clínicos devem contatar um dos autores. Como referido, o entrevistador deve estar familiarizado com psicopatologia geral e especialmente com as perturbações do espectro da esquizofrenia, bem como a perspectiva fenomenológica na psicopatologia.

\section{Propriedades psicométricas}

Os dois estudos iniciais mostram elevada fiabilidade intercotadores para a EAWE. Num estudo com 11 pacientes acompanhados em ambulatório e 1 indivíduo em regime de internamento, em que ambos os avaliadores estiveram presentes durante as entrevistas, os valores para a média do kappa para domínios individuais variou entre 0,73-0,89 enquanto a média do kappa global foi de 0,79 . Um segundo estudo de 15 indivíduos 
internados considerava as classificações com um avaliador presente nas entrevistas e que as conduzia, e um segundo que observou entrevistas gravadas; os valores da média do kappa para os domínios individuais variou entre 0,74-0,95, e a média do kappa geral foi de 0,84 . [11]

\section{Domínios e descrições dos produtos e subtipos}

\section{Espaço e Objetos}

Descrição Geral. Os 17 itens no Domínio 1 referem-se a várias anomalias da experiência do espaço e dos objetos, ou das qualidades do input sensorial. A maioria dos itens referem-se à visão e experiência espacial do "mundo", mas são também consideradas outras modalidades. $\mathrm{O}$ foco principal são os aspectos estáveis ou estáticos do mundo (e não as formas de agir, o fluir, ou a mudança ao longo do tempo).

\subsection{Anomalias na intensidade ou na persistência de percepções visuais}

As cores, a luz ou imagens inteiras são observadas como mais ou menos intensas que o habitual, por exemplo deixando de desvanecer para o fundo perceptual ou permanecendo mais tempo do que o habitual. Pode estar associado a um aumento ou a uma diminuição da sensibilidade a estímulos visuais.

1.1.1 Aumento de intensidade de percepções visuais* ( BS C.2.2.1)

As cores e a luz parecem mais fortes ou mais brilhantes. Pode aparecer como um aumento da sensibilidade a percepções visuais, ou como uma alteração das percepções em si.

• "As cores parecem ser mais brilhantes agora, quase como se fossem luminosas." [12]

- "O que costumava ser verde, agora tornou-se verde escuro. A cor de um milharal parecia diferente, mais intensa e violenta. Tudo parecia diferente e não natural." [13]

1.1.2 Diminuição de intensidade de percepções visuais * 
O sujeito declara que as cores e luz parecem ter desvanecido, serem mais fracas ou menos intensas. Pode aparecer como uma diminuição da sensibilidade às percepções visuais, ou como uma mudança do próprio objeto perceptual.

- "Vivo num mundo entediante, é verdadeiramente entediante. Eu não penso que existam quaisquer cores nele "(dados não publicados) (também marcar/pontuar 5.1.2, Intensidade ou substancialidade diminuídas*)

• "As cores estão mais apagadas e assim como a sua significância" [14] (Ver também 5.2, Perda de affordances)

1.1.3 Recorrência ou prolongamento de estímulos visuais (=BS C.2.3.12)

O sujeito continua a ver estímulos depois de estes já terem desaparecido do seu campo visual ("palinopsia"). Esta apresentação pode ser contínua ou recorrente.

- "Às vezes, eu continuo a ver coisas que já não estão lá, por exemplo, um carro que já passou. Estas permanecem diante dos meus olhos por um tempo. ... Como um eco visual." [1]

- "O chapéu, inicialmente visto numa pessoa, volta, na posição correta que ocupava, colocado noutras pessoas." [15]

- "Às vezes, vejo padrões abstratos que vi há algum tempo atrás. Eles persistem por vários dias no mesmo lugar no meu campo visual; quando eu movo minha cabeça, eles continuam." [1]

\subsection{Cegueira ou cegueira parcial (=BS C.2.1)}

O sujeito tem a experiência de que a sua visão está distorcida ou é imprecisa, ou que parte de um objeto ou do campo visual estão ausentes.

\subsubsection{Visão turva* (=BS C.2.1.1)}

Visão turva, imprecisa, fosca. Pode ser transiente ou ter maior duração, ser estável ou flutuante.

• "A minha visão diminuiu. Vejo tudo nebuloso e embaçado como se através de um véu." [1] (Considerar também 5.1.1, Afastamento tipo barreira (sensação placa de vidro)*)

• "Ao ler, minha visão torna-se pouco clara, as letras parecem estranhas." [1]

\subsubsection{Visão parcial (=BS C.2.1.3)}

O sujeito só percebe parte de um objeto, com outras partes da percepção em falta. 
- "Quando alguém me mostra a mão eu só consigo ver os últimos 3 dedos. A parte acima da linha na diagonal que vai do indicador ao dedo minúsculo está cortada." [1]

\subsubsection{Cegueira transitória (=BS C.2.1.2)}

O campo visual do sujeito fica temporariamente ausente da percepção, quer em sua totalidade quer apenas em parte.

• "Sempre que eu quero focalizar um objeto, ele desaparece diante dos meus olhos." [1]

• "O caminho, a galinha e a sala de repente tornaram-se subitamente invisíveis." [1]

\subsection{Perturbação da veracidade (precisão) das percepções visuais*}

O sujeito relata ter visto mal alguns objetos visuais (por exemplo, uma sombra é vista como uma cobra) ou ter visto coisas que claramente não estavam lá. A experiência pode ser quase-visual, como se a meio caminho entre o ver e o imaginar. NB: $\mathrm{O}$ foco deve ser sobre a natureza da experiência original, mais do que sobre uma avaliação que faz posteriormente. Mais ainda, a consideração destas experiências como tendo a qualidade de "realidade"/"serem reais" (assim este subtipo) pode ser difícil de especificar. Se o subtipo não for óbvio, deve-se escolher o subtipo ou subtipos mais apropriados, registando todos os detalhes relevantes que possam clarificar a natureza da experiência.

\subsubsection{Ilusões visuais*}

O sujeito diz ter interpretado erradamente um estímulo visual externo real ou ter considerado esse estímulo como algo totalmente diferente (o sujeito reconhece a percepção como não sendo realmente inerente ao estímulo externo). A experiência pode ter a propriedade de "como se" em vez de ter uma qualidade literal. É um caso mais severo do que confundir algo brevemente com o canto de seu olho, ou devido à escuridão, etc. A percepção tipicamente persiste apesar de uma inspeção cuidadosa ou prolongada.

- "As coisas parecem adquirir a sua forma espontaneamente; os buracos redondos nas janelas [as dobradiças] transformam-se em cabeças e parecem estar a morder-me." [14]

- "Eu via em todas as árvores e arbustos, em vez dos habituais corvos, figuras estranhas com contornos sombrios, indivíduos barrigudos com pernas compridas e narizes largos e longos, ou num outro momento elefantes de trombas longas sendo balançadas." [14 ] 


\subsubsection{Alucinações visuais*}

Experiência de sensações visuais ou percepções que têm muito pouca ou nenhuma base na realidade externa. Os fenômenos em questão possuem uma qualidade de quase-reais ou quase-externos (o sujeito, entretanto, pode não sentir este fenômeno como totalmente objetivo ou completamente equivalente a percepções normais). Considerar este item requer consciência crítica para reconhecer, em retrospectiva, a natureza ilusória da experiência anterior.

- "Eu via saírem da pele das pessoas raios de luz pretos e amarelos; o ar também fícou impregnado com raios e camadas estranhos..." [14]

- "Tenho estado o dia todo com medo dos animais selvagens que correm através das portas da minha casa, mesmo fechadas; eles movem-se lentamente no escuro, e vão ao longo da parede para logo se esconder em baixo do sofá e esperarem por mim lá..." [14] - "As figuras agruparam-se à minha volta a 3-6 metros de distância. Eram figuras humanas grotescas... estavam ali no espaço, mas é como se tivessem seu próprio espaço privado, um espaço que era peculiar a elas mesmas." [14]

\subsubsection{Pseudoalucinações Visuais * ( BS C.2.2.2)}

Como nas alucinações visuais (subtipo 2), o sujeito vivencia fenômenos visuais que não têm ligação (ou têm pouca ligação) a um estímulo externo; mas neste caso o sujeito está consciente durante a própria experiência de que estes fenômenos não têm base na realidade externa.

- "Ele sentia muitas vezes que havia objetos coloridos navegando através de seu campo de visão." [16]

\subsection{Fragmentação Visual}

Um objeto ou uma cena que são normalmente sentidos como um todo coerente parecem ser interrompidos ou perder a unidade que lhes seria característica.

\subsubsection{Fragmentação do objeto}

Objetos individuais são vistos como sendo compostos de várias partes individuais separadas. É difícil ou mesmo impossível observar as coisas como um todo. A fragmentação pode envolver coisas e pessoas. Pode incluir a decomposição ou divisão de objetos não apenas nos seus componentes (por exemplo, uma cadeira em pernas, em uma almofada, etc.) mas também em partículas. 
- "Eu é que tenho que agrupar as coisas na minha cabeça. Se eu olhar para o meu relógio não o vejo, mas sim a pulseira, a face, as minhas as mãos. Assim tenho de me esforçar para os juntar numa única peça." [17]

- "Pois eu via as características individuais do rosto, separadas umas das outras: os dentes, o nariz, em seguida as bochechas, depois um dos olhos e só por fim o outro." [18]

\subsubsection{Fragmentação de uma cena}

A cena, a paisagem, ou o mundo em volta perdem unidade de coesão; objetos parecem isolados, desligados do contexto, e talvez com menos significado. Pode ser vivenciado literalmente como uma separação física entre os objetos, ou como um sentimento geral de que os objetos não estão relacionados com os outros. NB: Se a pessoa tentar compensar esta perturbação esforçando-se, de forma consciente, em dispor as coisas de volta no seu lugar, o entrevistador pode registrar "construção consciente do contexto ou cena." [19]

• "... o espaço é infinito, irreal, onde tudo parece desligado, nu e isolado." [18] (também marcar 1.8.5, Experiência de infinitude do espaço)

- "... via o ambiente apenas em fragmentos... não era capaz de apreciar o todo... eram apenas como que "detalhes" num cenário sem sentido." [19]

- "Está tudo despedaçado. Tens de construir a imagem na tua cabeça bocadinho a bocadinho. É como uma fotografia que está rasgada em pedacinhos e a tens de ligar de novo ... E se eu me mover há uma nova imagem e sou obrigado a fazer isto tudo de novo." [12]

1.4.3 Captação da atenção por detalhes isolados (= BS C.2.9, = EASE 1.12.1). Certos detalhes de um objeto ou de uma cena parecem destacar-se sem nenhuma razão, chamando a atenção do sujeito. Ele pode não se sentir capaz de desviar o olhar ou a atenção. Pode incluir um objeto específico, um detalhe ou características (tais como cores, linhas, formas ou texturas), que normalmente não seriam salientes ou chamariam a atenção.

- "Às vezes um objeto destaca-se. Aí, os meus olhos têm que corrigir esse detalhe, é como se estivesse fascinado, apesar de eu não desejar estar a assistir a isso." [1]

- "Não só a cor das coisas me fascina, mas também todos os tipos de pequenas coisas como marcas na superfície, tudo isto chama a minha atenção." [12]

\subsection{Desorganização ou perturbação da estabilidade de um objeto}



ou cenas.

1.5.1 Desorganização do contorno dos objetos (= BS C.2.3.10).

Os limites ou contornos de um objeto são percebidos como estando perturbados, quebrados, a desintegrar-se, ou de outra forma comprometidos. O sujeito pode ver os contornos como tendo "quebras, dobras, curvas ou como sinuosos." [1]

\subsubsection{Perda de estabilidade perceptual (fluidez ou contaminação)}

As coisas ou objetos parecem mudar de forma ou significado ou transformar-se perante o olhar do indivíduo. No extremo, algo pode mesmo parecer ser dois objetos diferentes no mesmo momento, semelhante a uma dupla exposição fotográfica. (é exemplificada nas respostas Rorschach pela "fluidez" e "contaminação".)

• "Eu não vejo objetos, coisas ou pessoas inteiras ... os objetos não me parecem estáveis. Eles brilham intermitentemente para logo depois se tornarem deslocados, fazendo com que tudo pareça como se estivesse num estado de fluxo." [15]

- "Os padrões parecem libertados da sua prisão, da sua imobilidade aparente para logo se torcerem, dilatarem-se em ondas, recenderem ou diminuírem" (Dados não publicados)

- O sujeito vê num objeto simultaneamente uma "folha verde intacta" mas também como "uma folha amassada" (Dados não publicados)

1.6 Mudanças na qualidade, tamanho ou forma da percepção visual

Objetos parecem ter mudado de cor, tamanho ou da forma como seriam habitualmente percebidos.

1.6.1 Alterações na cor das percepções visuais (= BS C.2.3.4).

As cores parecem mudar de tonalidade - quer afetando certos objetos quer a coloração de todo o campo visual.

• "Enquanto o indivíduo está lendo, o papel branco de repente parece vermelho e as letras, verdes. Os rostos das pessoas parecem ficar com uma tonalidade peculiar castanha..." [14]

- "De repente, parecia que via através de óculos de vidro amarelo. E noutros momentos tudo ficava intensamente vermelho-escuro." [1] 


\subsubsection{Micrópsia / macropsia (= BS C.2.3.2)}

Os objetos são percebidos como (ou de alguma forma sentidos como) menores ou maiores do que realmente são. O entrevistador deve registar se é menor ou maior.

• "Todas as coisas estavam tão pequenas e distantes." [1]

• "A mobília parecia pequena e distorcida, o quarto longo e largo." [1]

- "Eu estava sentado a ouvir outra pessoa e de repente ela ficou menor e depois maior e depois novamente menor..." [17]

- "...mas quanto mais perto nos aproximamos uns dos outros, mais alta ela ficava, mais ela crescia em tamanho." [18]

\subsubsection{Dismegalopsia (= BS C.2.3.11)}

"Os objetos parecem maiores do que realmente são de um lado e menores do outro." [1]

- "Os objetos pareciam de certa forma distorcidos, mais altos de um lado e mais baixos no outro." [1]

\subsubsection{Metamorfósia (= BS C.2.3.3)}

A forma de um objeto é percebida como diferente ou distorcida face à sua real aparência. NB: Diferente do item 1.5.2, Perda da estabilidade perceptual, pois aqui a mudança já ocorreu. Além disso, a experiência não se assemelha a uma dupla exposição fotográfica.

• "As mercadorias pareciam peculiarmente diferentes, alteradas e deformadas." [1]

\subsubsection{Outras distorções (= BS C.2.3.8)}

As percepções visuais parecem vistas como "duplas, oblíquas, jargão ou invertidas." [1]

• "Por um bom tempo, eu via em duplicado." [1]

• "As casas eram todas tão tortas, pareciam não se aguentar direito." [1]

\subsection{Distúrbios da distância perceptual ou da justaposição dos objetos}

Várias perturbações ao estimar distâncias espaciais ou a justaposição dos objetos. 
1.7.1 Objetos parecem estar mais perto ou mais longe * (= BS C.2.3.1)

O sujeito percebe os objetos como estando mais perto ou mais longe do que seria normal, mas sem identificar uma mudança no tamanho (como acontece no item 1.6.2, Micrópsia / macropsia). Pode aplicar-se tanto às percepções visuais como às auditivas. $\mathrm{O}$ entrevistador deve registar se é mais perto ou mais longe. NB: A perturbação deste tipo pode também ser expressa por uma perturbação na estimativa de distâncias no geral, sem referência a um objeto ou percepção em particular.

• "As coisas pareciam tão distantes; tudo estava numa certa distância." [1]

- "Todas as coisas pareciam ter-se aproximado, como se estivesse a olhar através de um telescópio." [1] (Considerar também 5.1.1, Afastamento ou barreira (sensação de placa de vidro)*)

- "certas irregularidades espaciais distorciam as minhas percepções, parecia acontecer um afundamento das escadas e fazendo com que os corredores da escola ficassem telescópicos." [20]

1.7.2 Perturbação da posição espacial relativa (justaposição) de objetos

A relação espacial entre os (ou a justaposição dos) objetos, ou a sua proximidade em relação ao observador, fica desorganizada ou talvez mesmo inversa (por exemplo, um objeto mais distante parecer mais próximo do que um mais perto). Pode ser difícil determinar o que está no fundo e o que está no primeiro plano ou como os objetos se relacionam entre si espacialmente.

- "Várias vezes via as coisas mudarem de posição, em perspectivas confusas umas em relação às outras." [1]

1.7.3 Perturbações gerais na estimativa da distância (= BS C.2.3.9)

O sujeito tem dificuldade em determinar a que distância ele está de um objeto ou pessoa.

- "Eu deixei de poder atirar coisas no lixo, falhava por mandar demasiado longe ou demasiado perto. Tinha perdido a minha sensação de distâncias." [1]

- "Eu vejo as coisas de forma plana... É por isso que eu estou relutante em avançar. É como se houvesse uma parede ali e eu pudesse chocar com ela. Não há profundidade ... Não consigo saber a que distância estão as coisas até estar em cima delas." [17] 
1.8 Distorção da experiência de espaço

A experiência da configuração global da estruturação do espaço está alterada ou é diferente do habitual.

1.8.1 Diminuição da orientação em perspectiva

O espaço não parece estar centrado no sujeito, como se o mundo não fosse observável a partir de uma perspectiva distinta e orientadora. Pode envolver uma experiência "isotrópica" do espaço ou uma "visão sem ponto de partida", como se estivesse a ver tudo de "todos os lados ao mesmo tempo".

- "Parecia que tinha perdido o sentido de perspectiva. Se copio um modelo de um desenho de um colega de escola, copio com uma falsa perspectiva do lugar que eu estava sentado. No ginásio não conseguia compreender os comandos, confundindo a esquerda com a direita." [18]

\subsubsection{Perda de orientação topográfica}

Os indivíduos sentem-se completamente perdidos ou desorientados mesmo em locais familiares e compreensíveis.

• "Houve um tempo em que eu fui para uma caminhada e eu não sabia onde eu estava."

- "Eu me perdi ... [e senti] uma falta geral de orientação. Não conseguia reconhecer nada do que estava à minha volta, pessoas ou lugares." [13] (Considerar também 3.12.2, As pessoas parecem não familiares de um modo estranho, e 5.1.7, Desrealização inespecífica / outra*)

1.8.3 Perda da integridade ou da estrutura espacial

É a própria estrutura do espaço que parece duvidosa, inconsistente, ou de alguma forma impossível; como "viver num desenho de Escher", um espaço inconsistente com geometria normal. O sujeito pode, por exemplo, descrever ter subido escadas e sentir que tinha chegado a algum sítio abaixo, ou como se uma sequência de salas não funcionasse de acordo com a geometria possível.

1.8.4 Perda da dimensionalidade 
Espaço ou os objetos que ele contém podem parecer planos ou bidimensionais, ou em qualquer outra forma; a tridimensionalidade em si pode parecer de certa forma ilusória.

- O sujeito descreve objetos como "meras imagens sobre tela" ou "como se fossem pintados em uma placa de janela." [21]

1.8.5 Experiência de infinitude do espaço

O espaço parece prolongar-se indeterminadamente ou ser "enorme". [15]

- "Eu ainda vi o quarto. O espaço parecia estender-se e continuar-se para o infinito, um vazio completo. Eu me senti perdido, abandonado à infinitude do espaço, que, apesar da minha insignificância, de alguma forma me ameaçava." [14]

• "... um espaço imenso sem fronteiras, sem limites, plano; um espaço lunar de rochas... este vazio longo..." [18]

\subsubsection{Inversão Figura/Fundo}

O sujeito experiencia estar mais consciente do espaço que rodeia os objetos do que dos objetos em si.

- "O ar ainda está ainda aqui, o ar entre as coisas no quarto, mas as próprias coisas não estão mais lá." [22]

- "Quando estou acordado, eu posso olhar para uma árvore ou um gato ou um pássaro e ver o ar em torno deles que às vezes se parece com água, por isso às vezes eu pinto essa água." [22]

\subsubsection{Experiência afetiva do espaço *}

O espaço em si adquire uma qualidade afetiva que se torna muito proeminente, muitas vezes de tonalidade negativa, um sentimento ameaçador, assustador ou de estranheza.

- "Então senti que aquela paisagem de outono [ficava permeada] com uma segunda 'atmosfera'. Era fina e invisível, até pouco detectável. Esse segundo espaço era escuro, vazio, assustador; era difícil dizer com precisão o que era." [13]

1.9 Anomalias da intensidade ou na persistência das percepções auditivas Sons e ruídos são ouvidos como mais ou menos intensos do que o habitual, como não desaparecendo no fundo, ou com uma duração mais longa do que a 
habitual. Pode estar associado ao aumento ou diminuição da sensibilidade a estímulos auditivos.

1.9.1 Aumento da intensidade de percepções auditivas * ( BS C.2.4.1)

Os sons parecem mais alto e mais fortes. Pode aparecer como uma mudança real na intensidade percebida, ou como se o sujeito tivesse desenvolvido uma sensibilidade extraordinária a estímulos auditivos.

• "Eu sou hipersensível a qualquer tipo de som ou ruído. Quando estou doente, o ruído é mais alto. Todos os sons irritam-me." [1]

- "Ouço tudo com demasiada claridade e isso tortura-me, mais distintamente... tão alto que eu não quase não o aguento." [1]

1.9.2 Diminuição da intensidade das percepções auditivas * ( BS C.2.5.1)

Os sons parecem mais tênues ou mais silenciosos. Pode ser descrito como uma mudança na intensidade percebida ou vivenciado como mudança na sensibilidade às percepções.

• "Eu já não consigo ouvir como ouvia. O discurso soa-me muito suave e a música tão abafada." [1]

\subsubsection{Consciência das sensações auditivas "do fundo" aumentada}

O sujeito reporta ter consciência de sons do ambiente irrelevantes que normalmente diminuiriam por estarem presentes outros sons, mais salientes.

- "Tudo parece captar a minha atenção muito embora não esteja particularmente interessado em nenhuma dessas coisas. Estou a falar contigo agora mesmo, mas consigo ouvir o que se passa na porta ao lado. É difícil impedir-me de ouvir estas coisas, e pode ser mais difícil concentrar-me no que estou a falar contigo." [12]

1.9.4 Recorrência ou prolongamento de estímulos auditivos (= BS C.2.5.2)

Estímulos auditivos continuam a ser ouvidos, embora já tenham parado de ser emitidos minutos ou horas antes, possivelmente semelhantes a um eco. NB: pode sugerir também perturbação da vivência do tempo.

- "Um indivíduo voltou para abrir a porta várias vezes durante 30 minutos subsequentes à campainha ter tocado." [15] 
• "Às vezes, quando desligo o rádio o que eu ouvi no fim fica a ouvir-se por um bocado." [1]

1.10 Perturbações que envolvem a veracidade (precisão) de percepções auditivas*

O sujeito diz não compreender corretamente os sons - (como por exemplo confundir o som de uma madeira a ranger com alguém a chamá-lo) ou ouvir coisas que claramente não existem. A experiência pode ser quase-auditiva, como se a meio caminho entre ouvir e pensar. NB: $\mathrm{O}$ foco deve ser a natureza da experiência original, em vez de sua avaliação subsequente. Pode ser bastante difícil especificar o status de "serem reais" (daí o subtipo). Se o subtipo não é óbvio, escolher o subtipo mais apropriado, registando todos os detalhes relevantes que possam esclarecer a natureza da experiência.

\subsubsection{Ilusões auditivas *}

O sujeito diz interpretar erradamente um estímulo auditivo externo como algo totalmente diferente, por exemplo, palavras ou ruídos indistintos são ouvidos como algo sem relação ao som que percebeu. A experiência pode ser do tipo "como se" em vez de ter uma qualidade literal. Isto é mais grave do que simples casos de troca de sons/enganos, estes últimos breves e que desaparecem se o som for escutado com mais cuidado ou continuamente.

- O Sujeito ouve nas ondas do mar uma mensagem vagamente ameaçadora (Também marcar 5.8.2, Significado inerente ao próprio objeto)

- "A mais assustadora das [diferentes experiências semelhantes a vozes que já tive] foi as pessoas falarem, com o objetivo de me comunicarem ou influenciarem de várias formas... é difícil dizer se isso é um exagero do que alguém me está a dizer ou se era eu que estava 'a alucinar'... Eu não penso, na maioria das situações, que seja uma alucinação e sim que eu estou a exagerar o que estou a ouvir como se estivesse a interpretar algo de forma estranha embora isto não seja totalmente claro para mim." [23] (também marcar/pontuar 3.13, As pessoas parecem querer comunicar algo especial ou incomum)

\subsubsection{Alucinações auditivas *}

Experiências de percepções auditivas que têm muito pouca ou nenhuma base na realidade externa. Os fenômenos em questão são pelo menos qualitativamente 
quase-reais ou quase-externos, semelhantes, por exemplo, a ouvir a voz de alguém no quarto quando na verdade não há ninguém lá. ( $O$ sujeito não sente, porém, a experiência como totalmente objetiva ou equivalente a percepções normais). Este item implica o reconhecimento em retrospectiva da natureza ilusória da experiência anterior. NB: "As vozes" ou fenômenos semelhantes que não têm, pelo menos, propriedade quase-auditiva ou quase-externa (por exemplo, "São claramente pensamentos, mas não sou eu que os crio, são-me comunicados por alguém", [23 ] (considerar cotar também 3.7.5, Limites psicológicos fluidos ou fundidos); ou "as vozes que parecem mais internas, mais semelhantes a pensamentos" [23]), não devem ser cotados aqui, nem no subtipo 3.

• "Um sujeito ouvia frequentemente as palavras 'salsicha e batatas'." [24]

• "Parece mesmo como se alguém estivesse a falar comigo." [23]

• "Às vezes ouço a palavra ‘não'." [23]

\subsubsection{Pseudoalucinações auditivas * ( BS C.2.4.2)}

Como nas alucinações (subtipo 2), o indivíduo vivencia fenômenos auditivos que não estão fundados em um (ou estão apenas tenuemente associados a um) estímulo externo. Porém, neste item, o sujeito está claramente consciente durante a experiência do fenômeno que estes não têm base na realidade.

- "De vez em quando ouço alguns sons vagos, por exemplo, como o som de um animal ou como um assobio ou zumbido que martelam. Mas momentos depois eu percebo que estes sons não estão lá". [1]

• "(o pensamento) às vezes manifesta-se como ruído incrível." [25]

\subsection{Outras alterações na qualidade das percepções auditivas}

O sujeito descreve outras alterações da qualidade da experiência auditiva, por exemplo, sons percebidos como mais agudos ou mais graves do que habitual (como um guincho ou "chiar"), "abafados" ou de qualquer outra forma distorcida. Pode ser experienciado como se afetasse apenas um subconjunto de sons (por exemplo, certas vozes) ou todos os sons. Se isso for primariamente uma questão de compreender a comunicação linguística, deve-se considerar o Domínio 4. 


\subsection{Problemas na localização dos sons}

O sujeito tem dificuldades que determinar de onde vêm os sons, é confuso se vêm da esquerda ou da direita, da frente ou de trás, especialmente se a origem real do som não pode ser vista. NB: Não cotar se estiver apenas relacionado a alucinações auditivas ou pseudoalucinações.

- "... Às vezes fico um pouco confuso de onde vêm os sons... várias vezes pensei que alguém estava a gritar pela janela quando era na realidade o modem da casa da frente." [12]

\subsection{Distúrbios de outros sentidos * (= BS C.2.6)}

O sujeito experiencia sensações táteis (toque), gustativas (gosto) ou olfativas (olfato) diferentes do habitual.

\subsubsection{Perturbação do Tato (= BS C.2.6.3) *}

Os objetos são sentidos de forma diferente ou de certa forma alterados quando são tocados. Pode também incluir a persistência anômala de sensações tácteis já na ausência do estímulo, ou pode sentir como se estivesse a tocar ou ser tocado por algo que não está lá.

- "A sensação de toque tornou-se mais desagradável. Quando eu toco na madeira... em lã ou em papel, sinto uma sensação de queimadura nos braços e pernas." [14]

- "Quando eu toco em coisas ou no meu próprio corpo, sinto algo diferente do que antes. Quando eu coso, sinto as agulhas como diferentes, de certa forma pegajosas. E também, a lã macia parece diferente, como se fosse sarja." [1]

\subsubsection{Perturbação do Gosto* (= BS C.2.6.2)}

O gosto dos objetos é diferente para o sujeito. Pode referir-se a uma mudança geral no gosto, como este ser mais ou menos intenso ou mais ou menos agradável. Pode ainda ter experiências gustativas sem qualquer estímulo, ou uma fragmentação da experiência gustativa, por exemplo, saborear os ingredientes separadamente.

- "Parece que sou capaz de apreciar mais todas as coisas. O sabor é diferente e muito mais intenso do que antes." [14]

• "Eu não podia saborear nada, era tudo insípido e sem sabor." [1] 
• "Não consigo saborear a sopa pois sinto apenas os ingredientes separadamente. Saborear a sopa requer uma reconstrução." [26]

\subsubsection{Perturbação Olfativa * (= BS C.2.6.1)}

Mudança subjetiva na experiência dos cheiros, sentidos como qualitativamente diferentes, mais ou menos intensos, ou ainda mais ou menos agradáveis. Podem também experimentar cheiros alheio a qualquer estímulo.

- "Por quase meio ano, deixei de conseguir cheirar; por exemplo, eu não sentia o cheiro do leite queimado e não era capaz de diferenciar baunilha de café." [1]

\subsection{Sinestesia ou concomitância de percepção anômala *}

Uma experiência numa modalidade sensorial parece induzir automaticamente uma resposta sensorial associada numa modalidade diferente. Pode ser experienciado como agradável ou como negativo.

- "Para cada palavra que me era proferida ou dita perto de mim, cada pequeno ruído, eu sentia um golpe violento na cabeça, que produzia uma certa dor... como um repuxar intermitente na cabeça, provavelmente associado a um rasgar de parte do meu calote craniano". [14] (Considerar também 1.9.1, Aumento da intensidade de percepções auditivas.)

\subsection{Dissociação ou isolamento de percepções sensoriais}

Os fenômenos sensoriais parecem independentes, separados da sua fonte, como quando o discurso de uma pessoa, ou o som de um animal, parecem de alguma forma dissociados da pessoa ou animal de onde é visto ou sabido emanar. Pode ocorrer com todas as modalidades sensoriais, mas é mais comumente encontrado na percepção auditiva.

- "Um pássaro cantava no jardim. Eu ouvia-o e sabia que era um cantar de um pássaro, mas sentia que o pássaro e o cantar eram duas coisas diferentes em polos opostos." [14]

1.16 Distúrbios no reconhecimento ou identificação de objeto percepcionado (= $B S$ C.2.7)

O sujeito sente-se incapaz para (ou com um atraso significativo na sua capacidade de) reconhecer ou identificar um objeto nas percepções visual ou 
auditiva (que é, no entanto, claramente visto ou ouvido), por exemplo, saber que está vendo uma rosa ou reconhecer um som como o de um carro a acelerar ou frear.

- "As coisas que vejo claramente à minha frente não passam para a minha mente e eu continuo inseguro sobre o que vejo." [14]

- "Às vezes passo pelas pessoas e olho diretamente para elas, mas só depois, quando já passei por elas, é que as reconheço como familiares e me lembro que as conhecia bem." [14]

1.17 Perda de limites ou de demarcação com o mundo físico (=BS B.3.4.1, EASE 4.5)

$\mathrm{O}$ sujeito sente-se incapaz de determinar onde termina o seu corpo e onde começa o mundo exterior. É uma forma de miscigenação física em que os objetos externos parecem estar dentro e fundirem-se com o corpo do sujeito, ou o reverso. NB: Se a perda dos limites diz respeito à relação com outras pessoas, deve-se considerar o Domínio 3. Se a experiência envolve não tanto uma sensação de fusão, mas mais uma união mística, deve ser cotado o item 5.15.1, União mística com o mundo (embora os dois não sejam mutuamente exclusivos.)

- "Como eu estava olhando para o maço de cigarros na mão, de repente não tinha certeza se o pacote era parte do meu corpo ou não." [14]

- "Enquanto eu estava andando de bicicleta, de repente senti uma espécie de derretimento em minha bicicleta, como se a moto e eu tínhamos nos tornado um." (Dados não publicados)

\section{Tempo e Eventos}

Descrição Geral. Os seis itens do Domínio 2 referem-se aos modos sob os quais as ações, os eventos, as sequências ou o fluxo temporal podem ser vivenciados de forma anormal. Aqui o foco está nos aspectos temporais e dinâmicos do mundo, aqueles que envolvem movimento, memória, antecipação e mudanças ao longo do tempo. Note-se que dois ou mais destes aspectos podem, muitas vezes, ocorrer em conjunto; as experiências de déjà $v u$ ou jamais vu estão incluídas no Domínio 5: Ambiente. 
2.1 O tempo ou movimentos parecem mudar de velocidade ( BS C.12)

Distorção da vivência (a cada momento) do tempo ou movimentos, em que estes se apresentam acelerados ou lentificados. Tipicamente estas perturbações não estão relacionadas com o nível de atividade da pessoa e não devem ocorrer apenas em períodos de espera ou de excitação. [1]

\subsubsection{O tempo ou os movimentos parecem acelerados *}

- "Parecia-me que tudo estava acontecendo muito mais rapidamente do que antes. As enfermeiras e os pacientes moviam-se... mais depressa do que o normal. Quando o médico falou, soou rápido, alto e mais agudo." (paciente com esquizofrenia após coma insulínico) [27] (pontuar também em 1.9.1 - Aumento da intensidade das percepções auditivas e 1.11- Outras alterações na qualidade da percepção auditiva)

• "Os pássaros bicando muito mais rápido do que o realisticamente possível." [28]

• "O tempo passou muito rápido." [28]

\subsubsection{O tempo ou os movimentos parecem lentificados *}

• "A noite pareceu mais longa." [15]

• "Tempo mais longo e mais lento." [15]

• "O tempo dilatou." [15]

2.1.3 O tempo e os movimentos parecem (de alguma forma) tanto acelerados como lentificados.

• "O tempo mais lento, mais rápido, infinito/interminável." [28]

- "Movimentos da boca e discurso do outro estão desfasados: um mais rápido e outro mais lento." [28]

2.2 Discrepância entre tempo interno e externo * ( BS C. 2.12, EASE 1.14.1)

$\mathrm{O}$ sujeito relata sentimentos de que o seu relógio interno se desloca a uma velocidade diferente daquele do resto do mundo. Isso pode ser experienciado enquanto mudança no tempo interno, no tempo externo, ou em ambos; o crucial é a discrepância relatada.

2.2.1 O tempo interno parece mais lento do que o do mundo * 
O sujeito vivencia as suas ações, pensamentos ou emoções como imóveis ou muito lentas, enquanto as pessoas e os acontecimentos se movem a um ritmo normal ou mais acelerado.

- "As coisas lá fora continuam, os frutos nas árvores movem-se para trás e para a frente. Os outros caminham para lá e para cá na sala, mas o tempo não flui para mim ... O que é que o mundo exterior tem a ver comigo? Parece que eu choco contra ("bump up against time") o tempo." [29]

• "Sinto-me um gigante grande e lento." [28]

2.2.2 O tempo interno parece mais rápido do que o do mundo *

O sujeito sente que está a funcionar, ou a pensar, a um ritmo mais rápido do que o do mundo externo.

• "Senti que me movia normalmente e que todos os outros se moviam devagar." [28]

\subsection{Ruptura da organização dinâmica do tempo ( EASE 1.14.2)}

O sujeito sente que o fluxo ou a passagem do tempo normais não são mais vividos como certezas/garantias, isto é, não servem como um pano de fundo coerente (embora dinâmico) ao que experienciam. Ocorre uma ruptura da unidade ou síntese do vivido no passado e do que se está vivendo no momento, pelo que o momento presente experienciado incorpora, dentro de si, tanto o passado imediato (o que o filósofo Husserl [6] denominou "retenção" ou

"memória principal") como o futuro antecipado e iminente ("protensão" de Husserl).

2.3.1 O tempo é sentido como se estivesse completamente parado, estático, infinito, desaparecido

O sujeito pode experienciar o tempo como estando interrompido ou tendo chegado a um impasse. Pode ser como se se tratasse sempre do mesmo momento; como se o presente fosse tudo o que existe; como se o tempo estivesse congelado ou imóvel, tivesse deixado de fluir ou mesmo de existir de forma significativa; ou, talvez, como se um curto período de tempo se tivesse prolongado por um tempo muito mais longo do que era realmente o caso. Pode estar associado a sentimentos de significância pouco comuns, e também com espanto ou perplexidade acerca de sequências aparentemente óbvias de acontecimentos. 
- "É como se fosse sempre o mesmo momento... como um vazio intemporal." [14] (Considerar também 5.17.1, Vazio, entorpecimento, indiferença)

- "O pensamento parou, sim, tudo ficou parado, como se o tempo tivesse deixado de existir." [29]

• "Continuo a viver na eternidade, não há mais horas ou dias ou noites." [29]

- "Parei para acender um cigarro... de repente tive uma sensação como se tivesse estado ali umas duas horas... confirmei no relógio.... estava lá há poucos segundos." [1]

\subsubsection{O tempo como desarticulado ou fragmentado ( BS C.2.10)}

Uma perda do fluxo temporal normal e contínuo; em vez disso, os momentos parecem desconexos, desarticulados ou fora de sequência, talvez como uma sucessão de fotos ou instantes sem relação, ou como sob o efeito de uma luz estroboscópica. O fluxo de acontecimentos parece absolutamente aleatório ou arbitrário, sem uma causa, razão ou continuidade com sentido. A música, por exemplo, pode ser experienciada como uma sucessão de notas independentes, não relacionadas e desprovidas de unidade. Os movimentos observados podem ser experienciados como desordenados e sem sentido, como se isentos de uma direção orientadora ou um propósito organizador, por vezes como mera agitação.

- "A mão [do relógio] é constantemente diferente ... agora está aqui, depois ela salta, por assim dizer, e volta-se. Não é uma nova mão a cada vez?" [30]

- "Enquanto vejo televisão fica ainda mais estranho. Apesar de poder ver todas as cenas, não entendo o enredo. Cada cena pula para a próxima, não há nenhuma ligação." [31]

- "O curso do tempo é estranho, também. O tempo quebra-se e não anda mais para a frente. E aí surgem imensos e diferentes agora, agora, agora, todos loucos e sem nenhuma regra ou ordem." [31]

\subsubsection{Desorientação no tempo}

O sujeito experencia dificuldade ou confusão em situar acontecimentos na passagem do tempo ou com respeito à própria noção de tempo.

- "Estava constantemente a perguntar quando chegaria a minha mãe." (Dados não publicados)

• "Não me consigo lembrar do tempo." (Dados não publicados)

• "Olhava para o relógio e ele não significava nada." [28]

• "Era tudo como uma história. A meio do dia parecia que era noite. "[28] 
2.3.4 Sentir-se limitado ao momento presente

Dificuldades em representar, conceber ou sentir-se ligado ao seu próprio passado ou futuro, uma vez que a sua experiência se sente restringida ao presente. NB: Ver também 2.4.4, Colapso da protensão (orientação/direção para o futuro), e vários subtipos de 2.6, Experiência de memórias ou do passado perturbada.

- "De um momento ao outro, vários 'eu mesmo' aparecem e desaparecem totalmente ao acaso. Não há nenhuma conexão entre o meu ego presente e o anterior." [32]

- "Tudo está colapsado no presente, por isso acho que não vejo o futuro mais do que vejo o passado. Parece apenas existir um presente omnipresente e puro, eu acho." (Dados não publicados)

\subsubsection{Variadas experiências bizarras de tempo}

Incluindo uma sensação geral de estranheza, ou distúrbios mais específicos, tais como o tempo correndo para trás, senti-lo reduplicado, em loop ou repetindo-se a si próprio, ou de acontecimentos parecendo estranhamente atrasados, de controlar o tempo, ou de existir em múltiplas dimensões temporais. (Entrevistador deve registrar o exemplo.) NB: Sentimentos de reduplicação, loop, ou repetição são distintos de déjà vu (subitem 5.5), que descreve uma sensação geral de ter já experienciado as coisas antes, e também de recorrência de estímulos ou objetos (itens 1.1.3 e 1.9.4); neste caso, segmentos inteiros de tempo ou sequências de experiências ou acontecimentos parecem estar a repetir-se a eles próprios.

- "O tempo tem algo que mudou. Não deveria ser da forma em que está. Não sei de que maneira." [33]

- "Pensava que estava a controlar o tempo. Pensava que estava aqui e numa dimensão diferente ao mesmo tempo." [33]

• "O tempo voltando ao mesmo momento, vezes sem conta." [34]

- "... não era só o tempo que se repetia outra vez.... Um tempo estranho brotou. Tudo estava confuso, à toa, e sentia-me contraído em mim próprio." [29]

\subsection{Perturbação da antecipação}

O sentido normal de iminência, de direcionamento para um futuro imediato antecipado está de algum modo alterado ou perturbado. A ênfase aqui parece estar no enfraquecimento dos aspectos protensionais e/ ou retencionais normais da experiência temporal $[6,31]$. 


\subsubsection{Antecipação permanente}

A sensação de que algo muito importante (embora talvez não identificável) está sempre prestes a acontecer - de "algo iminente", de "viver num eterno e prenhe 'agora'" ou de "um estado de suspense." [21, 28] (também chamado de experiência ante festum [35] ou trema [36]). NB: Ao contrário de 5.14, Humor revelador ou pseudorrevelador, em que os objetos no mundo ou a experiência do mundo como um todo assumem um sentimento de estranheza ou de um caráter especial, a Antecipação perpétua tem um foco especificamente temporal (imediatez, iminência).

- "Então, tudo parecia parar, ficar à espera, prender a respiração, num estado de extrema tensão... algo parecia estar prestes a acontecer, alguma catástrofe extraordinária." [18]

2.4.2 Surpresa constante devido à incapacidade de antecipar acontecimentos futuros

O sujeito experiencia uma sensação pervasiva de novidade, surpresa ou ansiedade em torno de acontecimentos que, normalmente, não desencadeariam tal resposta (já que seriam expectáveis) - como se não experienciasse nenhuma continuidade com o passado, nenhuma "retro-continuidade", mas sem a perda de memória, no sentido usual. [37] O sujeito pode descrevê-lo como se o mundo estivesse constantemente a "começar de novo". NB: Ao contrário de 5.6, Experiências jamais vu, este item não precisa envolver uma sensação distinta e inquietante de se estar perante algo que deveria ser familiar e não é; além disso, geralmente envolve uma experiência mais contínua, em andamento, contrastando com as experiências relativamente discretas, típicas do jamais $v u$.

• "E tudo era novo para mim, tudo aquilo era novo para mim." [37]

- Todas as manhãs, "uma vez mais, tudo [parecia] sempre completamente diferente." [37]

\subsubsection{Sentimento de que "qualquer coisa pode acontecer"}

Com uma diminuição da resposta emocional associada. Não se trata apenas do sentimento comum de um futuro desconhecido, mas antes de que todos os acontecimentos possíveis de se desenrolar parecem igualmente prováveis ou improváveis, como se a habitual continuidade ou previsibilidade do mundo estivessem ausentes e quase tudo se pudesse passar em seguida. Portanto, a 
antecipação normal em relação a acontecimentos iminentes, e qualquer resposta emocional relacionada (por exemplo, surpresa ou prazer antecipado) são impossíveis. O sujeito pode notar a ausência de "“nervosismo antecipatório” ou de 'ansiedade"”. Pode incluir a sensação de que as leis da natureza, o senso comum, ou um fluxo coerente ou desenvolvimento de acontecimentos já não se aplicam; nesse caso, assinalar também 6.2.2, Liberdade conceptual/ Qualquer coisa serve. - "Por um lado, tenho esta estranha sensação de que qualquer coisa pode estar ao virar da esquina - monstros, o fim do mundo - por outro, tudo fica assim tipo 'e aí?'. Não há sentimentos de ansiedade, como se poderia esperar. Reparei nisto, e muitas vezes me pergunto por que é que essas possibilidades que normalmente assustam as pessoas, não têm nenhum impacto sobre mim." (Dados não publicados) (Considerar também 5.17.1, Vazio, entorpecimento, indiferença)

\subsubsection{Colapso da protensão (orientação/direção para o futuro)}

O sujeito relata uma perda da antecipação imediata: a sensação de que é impossivel mover-se naturalmente para o futuro iminente. (Aqui, a questão diz respeito à noção de tempo fluindo dinamicamente para o instante seguinte, não às expectativas relativas a um período de tempo futuro imaginado, como em 2.5.1, O futuro parece inexistente.) Também pode existir uma sensação de aprisionamento no presente (veja o item 2.3.4, Sentir-se limitado ao momento presente), ou até mesmo de se ser arrastado ou sugado para o passado (vide item 2.6.6, Intromissão do passado).

• "Tudo à minha volta está imóvel e congelado...Vejo o futuro apenas como uma repetição do passado." [38]

\subsection{Perturbação da consciência do futuro esperado *}

O futuro imaginado ou concebido (como tal, distinto do futuro imediato/iminente da protensão) é experimentado como irrelevante ou inexistente, como altamente ameaçador, como anormalmente conhecido ou então não revelado com antecedência.

2.5.1 O futuro parece inexistente. *

O sujeito é incapaz de pensar, imaginar ou apenas conceber a possibilidade de um período de tempo futuro (situação distinta da falta de sensação imediata de 
movimento em direção ou para o próximo momento, como em 2.4.4., Colapso da protensão). Pode, ou não, ser experienciado como angustiante para o sujeito.

- "Não sou capaz de ver o futuro, é como se não houvesse nenhum. Acho que tudo vai parar agora e amanhã não haverá nada de nada." [14]

- "[Sinto-me] muito desconectado de tudo o que possa acontecer no futuro... mesmo que saiba o que estou fazendo agora, não consigo tornar o meu futuro pessoal, como por exemplo... será que vou jantar? Tenho que ter um plano específico na minha mente para que o sinta como real. E como não posso prever este tipo de coisas, simplesmente não me sinto ligado ao futuro." (Dados não publicados)

• "Às vezes parece-me... que não há um futuro para mim. Não sei como explicá-lo. Tipo como quando é que o futuro continua por si e eu fico parado/para trás." (Dados não publicados)

2.5.2 O futuro parece não ter importância ou ser irrelevante *

Os acontecimentos futuros parecem desprovidos de qualquer significado ou carga emocional. O sujeito pode relatar sentir-se "indiferente" ou "apático" em relação a acontecimentos futuros esperados.

\subsubsection{O futuro parece ameaçador *}

O sujeito diz experienciar o futuro como sendo ameaçador ou esmagador, muitas vezes ao ponto de constituir um perigo para a sua própria existência. Pode descrever vários comportamentos ou técnicas usados para evitar pensar no futuro. - O sujeito relata sentimento de um futuro cheio de "prazos até aos quais teria que fazer certas coisas senão tudo iria parar." (Dados não publicados)

- "O futuro estava bloqueado [para o paciente] pela convicção de um evento destrutivo e aterrorizante [a sua execução]. Esta convicção dominava completamente as suas perspectivas." [29]

\subsubsection{Premonições *}

O sujeito descreve que, de algum modo, sabia o que ia acontecer antes que acontecesse. Isto pode variar de uma pista ou sensação de saber quais os eventos que vão ocorrer, à sensação de saber detalhes exatos sobre eventos futuros.

- "Senti que algo bom ia acontecer comigo." [28] 
O passado recordado é sentido de alguma forma alterado, seja excessivamente desligado, vago ou obscuro, desaparecido, excessivamente acelerado ou lentificado, desconexo ou intrusivo.

\subsubsection{O passado parece segregado *}

O sujeito sente-se dissociado de memórias passadas, como se o passado estivesse profundamente desconectado ou não relacionado com o momento presente (existindo de alguma forma, como um "tempo antes do tempo"), ou como se os acontecimentos passados, na realidade, nunca tivessem passado com ele próprio (teriam sido apenas imaginados ou sonhados, por exemplo).

- "Estava desligado do meu próprio passado, como se nunca tivesse sido assim, tão cheio de sombras... como se a vida tivesse começado só agora ..." [14]

- "[O passado é sentido] como algo que já foi lido num livro ou num romance, mas nunca realmente experienciado por si próprio." (Dados não publicados)

\subsubsection{O passado parece vago ou obscuro*}

Portanto, é difícil de lembrar. O sujeito pode descrever o passado como "perdido numa névoa."

\subsubsection{O passado desaparece ou parece inexistente *}

O sujeito não é, de todo, capaz de se recordar das experiências passadas e pode sentir que o passado nunca ocorreu realmente.

- "Por vezes [o passado] parece simplesmente não existir, portanto, uma memória, tipo o meu terapeuta pode dizer-me que alguma coisa aconteceu, e eu vou pensar ok, isso existe porque está me falando sobre isso agora, não porque tenha realmente acontecido... Às vezes acho que nunca fui uma criança, nunca tive uma infância, nunca tive um passado." (dados não publicados)

\subsubsection{O passado parece acelerado *}

Retrospectivamente, as memórias do passado parecem de alguma forma condensadas, como se uma sequência de acontecimentos de longa duração tivesse ocorrido ao longo de um período muito curto de tempo, ou como se os acontecimentos tivessem sido de alguma forma acelerados. 
- "Meses e anos voam com velocidade excessiva. [Um] sujeito sentia que um passado de vinte e nove anos tinha durado apenas quatro anos no máximo, e os intervalos de tempo menores dentro deste período teriam sido correspondentemente encurtados. "[14]

2.6.5 O passado parece mais lento *

O sujeito sente que memórias passadas estão prolongadas, ou que os acontecimentos ocorreram ao longo de um período de tempo muito mais longo do que o real.

- "A minha própria memória dá-me a impressão de que este período de tempo, 3-4 meses pelos cálculos normais, era imensamente longo para mim, como se cada noite tivesse a duração de séculos." [14]

\subsubsection{Intromissão do passado *}

O presente, e até mesmo o futuro, do sujeito são sentidos como de alguma forma esmagados ou superados pelo seu passado, como se ele já não fosse capaz de pensar em outra coisa, ou nada mais parecesse real em comparação.

- "Não há mais presente, apenas uma referência para trás, para o passado; o futuro continua encolhendo - o passado é tão intrusivo, envolve-me, puxa-me para trás." [14]

\subsubsection{Erosão da distinção entre passado e presente *}

O sujeito está inseguro sobre se está a recordar algo do passado ou a realmente vivê-lo no momento presente. Pode existir uma sensação de opressão pelo passado, mas aqui (ao contrário do subtipo 2.6.6, Intromissão do passado, ou 5.5, Experiências déjà vu), parece haver alguma confusão em torno do passado versus presente.

• "Pelo tempo parecia que eu estava de volta ao passado, e não o tempo de hoje." [15]

\subsubsection{Vivência de Desarticulação do passado}

Os acontecimentos passados aparecem, em retrospectiva, como desconexos, desarticulados, ou fora de sequência, em vez de uma série sensata de eventos.

- "Sinto como se tivesse perdido a continuidade que ligava os acontecimentos no meu passado. Em vez de uma série de acontecimentos ligados por continuidade, o meu passado parece apenas feito de fragmentos desconexos." [22] 
• "...então o passado deu meia-volta... tudo ficou entrelaçado, mas de nenhuma maneira compreensível; tudo encolheu, caiu em conjunto, empacotado." [14]

- "Quando a visita terminou, poderia muito bem ter acontecido ontem. Já não podia organizá-la, para que pudesse saber onde pertencia. "[29]

\section{Outras pessoas}

Descrição Geral: Os 14 itens no Domínio 3 referem-se a anomalias na experiência subjetiva de outros seres humanos ou do mundo interpessoal. Centram-se nas experiências de interação social, na empatia ou falta desta, nos limites interpessoais do eu e na forma como o sujeito vive o aspecto geral dos outros, o sentimento que lhes associa e que influência lhes atribui. As experiências que se centram na comunicação linguística (palavras, frases, ou o discurso) estão incluídas no Domínio 4: Linguagem.

3.1 Falta de compreensão social ou sintonia interpessoal (hipossintonia) ( $\sim B S$ A.7.1, EASE 2.12)

Um sentimento de distância extrema e desprendimento dos outros, envolvendo a sensação de que os movimentos, gestos ou discurso não estão coordenados com os das outras pessoas, de uma falta de sintonia não-verbal e, em particular, do senso comum social (dificuldade em compreender ou aderir às "regras do jogo"). Pode ser experienciado como uma perda da espontaneidade ou ressonância no envolvimento com o mundo social, e/ou como uma forma hiperreflexiva de autoconsciência ou ainda como um sentimento de alienação do seu próprio comportamento ou experiência. Este item significa mais do que um sentimento de se "estar dessincronizado" com os outros devido a formas de ansiedade social ou depressão, em que as regras do senso comum sociais estão mantidas. Não está restrito a pessoas ou situações específicas e envolve um sentimento generalizado (embora não necessariamente constante) de afastamento de quase todas as pessoas.

\subsubsection{Perda do senso comum social}

Sentimento de incapacidade de uma apreensão natural ou a compreensão espontânea do comportamento das outras pessoas ou do encontro social. 
• "As pessoas movem-se de forma estranha... fazem gestos, movimentos sem sentido." [30]

• "Eu simplesmente não consigo entender o que os outros fazem." [39]

\subsubsection{Perda de sintonia proprioceptiva/corporal}

O sujeito descreve um sentimento maioritariamente físico de ser desajeitado ou estar dessincronizado com as outras pessoas.

- "O meu primo acabou de ter um bebê, e sinto-me muito feliz, mas sou obrigado a pensar como estou mostrando este sentimento... não tenho a reação automática às coisas como as outras pessoas têm." (Dados não publicados)

- "Às vezes, é difícil mover-me ou fazer coisas naturalmente. Então, quando estou a jantar com outras pessoas e quero beber a bebida do meu copo, tenho de ter atenção às outras pessoas que o estão a fazer" (Dados não publicados)

\subsubsection{Dificuldade específica em compreender a comunicação não-verbal}

O sujeito tem dificuldade em compreender a comunicação não-verbal, ou percebe que compreende erradamente gestos ou expressões faciais dos outros.

- "Os gestos dos outros parecem-me muitas vezes estranhos... porque estou realmente atento aos movimentos deles." (Dados não publicados)

- "Estou, de facto, demasiado atento ou crítico ou até curioso em relação à linguagem corporal. Como por exemplo ... se eu estivesse a caminhar na direção de alguém que estivesse a se afastar de mim, seria fácil eu considerar que eles estavam a se afastar de mim intencionalmente." (Dados não publicados)

\subsection{Sentimento de distância dos outros * ( EASE 2.4.1)}

Sensação de estar separado, à parte, desligado, ou profundamente distante das outras pessoas, de não estar envolvido, mas observando os outros à distância, como um espectador contemplativo, sem uma ligação emocional espontânea. NB: Este item pode associar-se ou não a uma redução da sensação de sintonia interpessoal (ver item 3.1), constituindo assim também uma sensação de estranheza ou incapacidade de compreender o significado de situações interpessoais.

• "Eu isolei-me dos outros e fiquei fechado em mim mesmo." [40] 
• "Sinto um painel de vidro entre mim e a humanidade". [22]

• "Uma parede de vácuo isola-me das pessoas." [21]

\subsection{Estratégias intelectuais/idiossincráticas de compreender os outros}

O sujeito depende de observações racionais ou de métodos intelectualizados e baseados em regras para compreender e responder aos outros, devido a um sentimento de incapacidade de compreender de forma imediata as interações sociais do dia a dia.

3.3.1 Contemplação alienada do comportamento dos outros

O sujeito tem consciência de observar os outros, de forma a compreender as situações sociais e a perceber como viver (copiando os outros ou descobrindo a fórmula segundo a qual se comportam - neste último caso deve ser considerada também o subtipo 2, Estruturação matemática/algorítmica da compreensão social). Pode envolver um sentimento de que se é um estudioso envolvido na tarefa de observação "etológica" das outras pessoas ou na análise "científica" de sistemas ou máquinas "inteligentes".

- "Sou como um imperador na minha pirâmide. Não estou envolvido no mundo, estou de fora a observá-lo para compreender os segredos do seu funcionamento." [41]

• "Os outros sabem as regras; eu tenho que estudá-las." [41]

- "Quando eu era criança, costumava olhar para os outros para saber quando é que era suposto estar contente ou estar triste." [39]

\subsubsection{Estruturação matemática/algorítmica da compreensão/interação social} O sujeito tenta compreender ou responder aos encontros sociais descobrindo ou criando uma fórmula algorítmica explícita ou um conjunto de regras. Pode parecer movido por uma curiosidade teórica ou por uma tentativa de fazer face à realidade; pode sentir-se bem ou malsucedido.

• "Devo eu resolver os algoritmos para falar com ele." [39]

• "As pessoas têm um sistema. Eu tento compreendê-lo. Mas não consigo entender nada." [39]

3.4 Sentimento de inferioridade, crítica ou de desconfiança em relação aos outros * 
Sensação de extrema dificuldade em estabelecer relação ou sentir-se seguro com os outros por um sentimento de inferioridade ou experiência de hostilidade por parte dos outros.

3.4.1 Sentimento de insegurança própria, juízo crítico de si mesmo * Normalmente com sentimento de inferioridade em relação aos outros ou de consciência exacerbada dos próprios defeitos ou de uma inabilidade na interação com os outros.

- O sujeito pergunta-se a si próprio: "Por que é que eu tenho que pensar tanto sobre todas as pequenas coisas que faço?" e "Será que estou a fazer a coisa certa? Estarei a fazer o que outros considerariam aceitável?" (Dados não publicados)

\subsubsection{Sentimentos de "paranoia social" ou de ansiedade social*}

Sensação de que os outros estão estranhamente centrados em si, quer comentando, ajuizando ou simplesmente mirando-o de uma forma que faz com que o sujeito se sinta autoconsciente, culpado, envergonhado ou ansioso. $\mathrm{O}$ sujeito pode sentir-se especialmente vulnerável ou desestabilizado pelo olhar crítico ou pelas atitudes dos outros. NB: este item pode ser semelhante, ou concorrente, com os itens 5.12, "Paranoia" ontológica/Insegurança própria generalizada ou com o 6.10, Sentimento de centralidade, e podem ser inquiridos juntamente com estes.

- "Eu convenci-me que... toda a gente que me via sabia instintivamente que eu tinha uma incapacidade social... como se as pessoas quando se encontram comigo me tratassem com normalidade, mas na realidade estivessem a fingir e depois se rissem nas minhas costas quando eu me fosse embora." [42]

- "Eu sinto sempre quando entro numa sala que as pessoas estão a olhar para mim, a falar sobre mim, e conseguem saber o que eu estou a pensar. Sabem quão estúpido eu fui no meu passado." (Dados não publicados) (Considerar também o item 6.10, Sentimento de centralidade)

\subsubsection{Desconfiança pervasiva das outras pessoas *}

O sujeito tem uma sensação geral de que os outros não são de confiança ou que lhe desejam algum tipo de mal. Pode ou não incluir uma sensação de paranoia (subtipo 2) de que os outros estão focalizados em si de forma pouco comum. 
- "Assusto-me quando entro em contato com outras pessoas. Elas podem fazer-me mal. "[43]

\subsection{Angústia / Aflição por insegurança social generalizada ( BS A.8.2)}

A mera presença de outras pessoas é vivida como pesada, estressante ou mesmo
insuportável. Tipicamente envolve uma sensação de vulnerabilidade/
insegurança ontológica básica mais profunda que vergonha, culpa ou
sentimento de inferioridade social - como se o self se tivesse tornado instável e
vulnerável a ser destruído ou aniquilado pelos outros. Pode envolver emoções,
afetos negativos ou sensações corporais estranhas desencadeadas pelos contatos
interpessoais.

- "Embora eu goste de companhia, recentemente as conversas tornaram-se cansativas, estressantes. Até falar com os outros parece afetar-me." [1]

• "Estar com pessoas desencadeia-me uma crise emocional." [39]

• "Quando as pessoas ficam muito perto de mim eu sinto-me nervoso." [39]

\subsection{Interferência por vozes *}

O sujeito sente-se incapaz de participar em situações sociais devido a vozes (alucinações ou imaginadas) que o distraem ou desorganizam.

- "Lidar com as três [vozes] juntas... o som era mesmo tremendo. Eu não conseguia pensar... não conseguia concentrar-me, nem fazer certas tarefas pois estavam sempre a falar comigo" (Dados não publicados)

\subsection{Perturbação da demarcação eu-outro (= EASE 4.1)}

O sujeito sente que o seu sentido básico de independência ou a distanciação entre si e o outro foram quebrados ou se tornaram muito mais fluidos do que o normal. Pode envolver sentimentos intensos de empatia, de abertura, de controle, de fusão ou confusão entre si e o outro - quer físicos, quer psicológicos, quer relacionados com a sua identidade.

\subsubsection{Hipersintonia}

O sujeito sente que pode "ler" ou compreender a mente dos outros de uma forma direta, como se tivesse acesso imediato à consciência do outro, por exemplo 
quando essa pessoa está em silêncio ou tendo acesso ao "verdadeiro significado" das palavras do outro quando este afirma o oposto (excluindo-se a utilização de ironia, etc.).

• "Eu sofro de empatia e identificação extremas." [43]

\subsubsection{Influência incomum sobre os outros}

O sujeito sente-se capaz de controlar os pensamentos, sentimentos ou ações dos outros, de uma forma imediata ou não natural (e não apenas por meio de formas normais de influência).

- "As pessoas para quem eu olho, eu faço com que elas fiquem com os meus próprios pensamentos." [44]

- "O meu raio de radar sempre me deu imenso prazer... Sou capaz de o lançar ou recolher de acordo com a minha vontade... de o mover para dentro dos meus olhos e olhar furiosamente para um inimigo qualquer, e ele vai ficar pálido, assustado e afastar-se de mim." [45]

\subsubsection{Abertura patológica}

O sujeito sente que os seus pensamentos, sentimentos ou a sua alma/self estão de certa forma expostos, e que os outros conseguem entrar ou conhecer diretamente os conteúdos da sua mente.

- "É como se eu tivesse um buraco... às vezes é como se eles entrassem dentro de mim através dele." [43]

• "Eu sinto as pessoas a entrarem dentro de mim." [43]

\subsubsection{Experiência de ser controlado}

O sujeito sente que os seus pensamentos, sentimentos ou ações são controlados pelos outros (de uma forma especial, como no subtipo 2).

• "Há pensamentos que se impõem quando aparecem na minha cabeça, e estão sempre na parte detrás da cabeça, na verdade, perto do tronco cerebral, e parece que estou a ser dominado por uma sensação estranha de fazer coisas que eu não quero fazer." (dados não publicados)

- "... os vizinhos podiam ler a sua mente, fazê-la ir no caminho errado na rua para impedila de ver homens e fazê-la pensar pensamentos violentos porque percebiam que ela gostava de homens." [33] (também marcar subtipo 3, a abertura patológica) 


\subsubsection{Limites psicológicos fluidos ou fundidos}

O sujeito sente que a sua mente é invadida, misturada ou penetrada, como se experienciasse os pensamentos, sentimentos ou memórias de outras pessoas, ou se sentisse inseguro sobre a quem pertenciam as experiências - experiências normalmente desagradáveis ou desencadeadoras de ansiedade, frequentemente com incerteza ou confusão quanto aos limites psicológicos.

- "Gradualmente deixei de distinguir quanto de mim está em mim e quanto já estaria nos outros." [22]

- "As pessoas parecem torturar a minha mente. Há espíritos a saltar para a minha mente. Parece que formas de telepatia estão envolvidas nisto." [33]

• "Sinto os estados mentais dos outros e já não consigo encontrar-me a mim próprio." [43]

\subsubsection{Fusão universal}

O sujeito sente como se as pessoas simplesmente não existissem como indivíduos distintos, mas como se de alguma forma elas estivessem fundidas, com um funcionamento similar à mentalidade de colmeia ou com uma consciência unificada.

• "Eu sinto-me imerso na torrente dos humanos." [43] (tradução alterada)

\subsubsection{Incerteza sobre atitudes ou identidade pessoais *}

O sujeito sente-se confuso sobre a sua identidade, atitudes ou preferências na presença de outras pessoas, como se fosse incapaz de resistir a conformar-se ou incapaz de manter perspectivas autônomas separadas. $\mathrm{O}$ problema aqui diz respeito à autenticidade das suas próprias opiniões e atitudes ou à confiança que tem nelas (e não ao próprio sentido de ter ou viver experiências pessoais).

- "Se estou com a minha mãe, comporto-me mais como a minha mãe; se estou com a minha irmã, sinto-me mais como a minha irmã." (Dados não publicados)

\subsubsection{Incerteza quanto aos limites físicos ( EASE 4.3)}

$\mathrm{O}$ sujeito sente-se confuso quanto aos limites ou à diferenciação das suas características físicas ou das suas partes do corpo e as de outras pessoas.

- "Tento sempre evitar contatos físicos, já que quando as pessoas me tocam eu sinto que elas penetram dentro de mim." [43] 
• "Os corpos das outras pessoas misturam-se com o dela." [46]

- Um paciente referindo-se às outras pessoas na enfermaria disse: "Estavam todos em movimento, correndo para dentro da minha cabeça... balançavam-se em círculos, empurrando-me a cabeça para fora." [47]

\subsubsection{Experiência de ser imitado (= BS C.1.18)}

O sujeito sente como se as outras pessoas estivessem a imitar os seus movimentos e ações ou talvez a fazer piada de sua forma de agir com imitações exageradas. A imitação é vivida como tendo uma qualidade peculiar, estranha ou fora do normal. NB: Ao contrário do item 5.13.4, Pseudomovimentos de objetos e pessoas, em que o sujeito tem a sensação de que as pessoas estão imitá-lo ou espelhá-lo intencionalmente.

- "Quando estava à espera do comboio, vi um tipo na plataforma do outro lado, e tive a impressão que ele estava a fazer exatamente o mesmo que eu, como se fosse a minha imagem no espelho." [1]

- "À medida que ela viu um grupo de passageiros a sair do autocarro teve a sensação que eles estariam a gozar representando-a. ${ }^{15 "}$ [2]

\subsection{Dificuldades com o olhar}

Sentimento de dificuldade ou desconforto no contato visual. O sujeito apercebese particularmente do contato visual ou do olhar dos outros, sentindo-se intrigado ou enervado e tentado a analisá-lo.

\subsubsection{Intromissão do olhar do outro}

O olhar da outra pessoa é visto como penetrante e intrusivo, talvez até mesmo difícil de suportar. O sujeito pode descrever ter de desviar o olhar ou olhar para baixo para não se perder.

- "Vejo o olhar das outras pessoas como perfurantes, como se me estivesse a esfaquear." (Dados não publicados)

- "Quando olho nos olhos dos outros, sinto-os como muito fortes, quase impossíveis de suportar." (Dados não publicados)

\footnotetext{
${ }^{15} \mathrm{Na}$ variação linguística brasileira, a tradução poderia ser: "À medida que ela viu um grupo de passageiros saindo do ônibus, teve a sensação que eles estavam fazendo piada imitando-a.”
} 
3.8.2 Sentimento de exposição ao ser olhado nos olhos ( EASE 4.5)

O sujeito sente-se exposto ou à mercê pois a sua vida interior é revelada quando é olhado pelos outros nos olhos, ficando com acesso imediato às suas emoções e pensamentos. Pode ter uma qualidade somática/física, como se os olhos pudessem ser fisicamente penetrados.

- "Quando alguém olha para mim, sinto-me exposto. Fico embaraçado quando o outro consegue literalmente ver o que se passa no meu interior." (Dados não publicados)

\subsubsection{Intromissão do próprio olhar}

O sujeito sente o seu próprio olhar como penetrante e perturbador para outras pessoas, como se transmitindo algo mau ou desagradável, talvez "energia" negativa por meio dos olhos.

• "Eu sinto constantemente que espalho energia negativa por meio dos olhos." (Dados não publicados)

- "Às vezes sinto que as pessoas ficam irritadas e inquietas quando faço contato visual com elas." (Dados não publicados)

- "Preocupa-me que ao olhar para as pessoas as possa ferir de alguma forma." (Dados não publicados)

\subsubsection{Desumanização dos Olhos dos Outros}

Pode haver um sentido que, olhando nos olhos dos outros, persuada o sujeito a pensar que não estão realmente vivos ou conscientes, elou tenham uma qualidade desconcertantemente tipo-objeto ou material. Olhos ou globos oculares de outra pessoa (ou do próprio, vistos num espelho) podem parecer, por exemplo tipo "berlindes ${ }^{16}$ estranhos" ou como tendo um brilho desconcertante "estilo vidro" ou "metálico".

\subsubsection{Olhos como Portais Cósmicos}

O sujeito descreve um sentido desconcertante (uncanny) de que os olhos dos outros (ou do próprio, vistos num espelho) se abrem para dimensões "místicas"; "cósmicas" ou "espaciais".

\footnotetext{
${ }^{16}$ A expressão, na variedade linguística brasileira, se refere a "bolas de gude estranhas".
} 


\subsubsection{Inquietação Inespecífica do Olhar}

O sujeito sente uma inquietação e ansiedade inespecíficas enquanto estabelece contato visual com outra pessoa, mas é incapaz de especificar por quê. Prefere não olhar nos olhos dos outros.

- "Quando estabeleço contato visual com alguém, sinto-me inquieto. Não consigo descrever exatamente por quê, mas me sinto impelido a evitá-lo ou pelo menos a olhar para outro lado.” (Conteúdo não publicado).

- "Quando olho alguém nos olhos sinto vibrações estranhas dentro de mim". [43]

- "Nunca fui capaz de aguentar o olhar dos outros". [37]

\subsection{Despersonalização dos Outros}

As outras pessoas são experienciadas não como seres humanos vivos e respirantes, mas como de algum modo mortos, irreais, ilusórios ou mecânicos. Pode ser selecionado mais do que um subtipo. NB: Se outros objetos ou situações são incluídos neste sentimento, deverá avaliar-se apropriadamente o subtipo 5.1, Desrealização do mundo.

\subsubsection{As Pessoas Parecem Mortas*}

As pessoas vivas têm uma qualidade especificamente cadavérica. Esta envolve um sentimento forte da mortandade dos outros e pode ou não implicar uma convicção de que o sujeito está, de facto, morto (como no delírio de Cotard).

- “As pessoas pareciam estranhas como se estivessem mortas." [15]

- "As coisas estavam mal. Era como se estivesse no submundo. Foi como um sonho. Tudo o que podia ver eram pessoas em um carro. Elas pareciam fantasmas, estátuas, monumentos, como que cremadas." [33] (pontuar/marcar 5.1.3, Perda de vitalidade/ Inanimação *)

\subsubsection{As Pessoas Parecem Irreais/Falsas/Ilusórias}

O sujeito percepciona as outras pessoas como se fossem artificiais, estranhamente fraudulentas, ou como cópias delas mesmo (ainda que não disfarçadas; ver 3.12.3, Pessoas parecem disfarçadas*, abaixo). Podem parecer também como se não fizessem parte da realidade normal objetiva/intersubjetiva ou, em vez disso, subjetivizadas, por exemplo, parecendo míticas, ficcionais ou imaginárias. 
- “As pessoas parecem-me diminuídas em tamanho e feitas de papel ou algodão, como pequenas peças de xadrez em papel machê." [Conteúdo não publicado].

\subsubsection{As pessoas parecem mecânicas}

O sujeito percepciona as outras pessoas como se fossem máquinas e por isso desprovidas de vitalidade, subjetividade ou vida interior.

- "Ela parece... um manequim movido por um mecanismo, falando como um autômato... os movimentos estão desprovidos de emoção ou sentimento." [18]

\subsection{As pessoas são dominadas por uma característica única}

O carácter ou aparência de uma outra pessoa parece completamente definido por uma única característica em particular ou limitado a ela, como se a pessoa lhe fosse inseparável, completamente resumida ou revelada por ela, como a forma do nariz, o modo de andar, o gesto típico ou o comentário.

- "Sempre que estou com outras pessoas, olho para o modo como posicionam os pés: estão virados para dentro, fora, ou completamente retos. O posicionamento dos pés contame quem são eles e em que acreditam.” [Conteúdo não publicado]

- "As cores das roupas que as pessoas vestem contam-me uma tremenda quantidade de coisas sobre os seus valores e aquilo em que acreditam." [Conteúdo não publicado]

\subsection{Intensidade aumentada, vivacidade, ou realidade dos outros*}

As pessoas são experienciadas como de alguma maneira mais intensas, vivas ou reais que o habitual, de um modo que parece anormal, desconcertante (uncanny) ou não completamente humano.

- Uma informante relatou que experienciava os outros como "deuses, manifestações (faces) de um só deus [ou] de poderes sobre-humano"; ela descreveu "aumentos no dinamismo metafísico, animismo universal, ressonância emocional, determinação humana e/ou divina." [48]

\subsection{Alterações na qualidade ou tom da aparência dos outros}

A aparência das pessoas, ou o modo como esta é experienciada, é alterada de uma forma estranha ou desconcertante (uncanny).

3.12.1 As pessoas parecem familiares de um modo estranho 
As pessoas desconhecidas ao sujeito parecem familiares de um modo estranho ou desconcertante (uncanny). NB: Se objetos não humanos, situações ou eventos estão também incluídos neste sentimento, pontuar também 5.5, Experiências dejá $v u$.

- "A paciente relatou que não conseguia deixar de notar que via caras na clínica que tinha visto já em casa algumas semanas antes.” [14]

3.12.2 As pessoas parecem não familiares de um modo estranho

As pessoas que são, de facto, familiares ao sujeito, e cuja aparência é reconhecida, têm ainda assim uma qualidade não-familiar impressionante. Tal pode ou não implicar a convicção de que os outros indivíduos deverão ser na verdade uma pessoa desconhecida, talvez disfarçada como íntimo (neste caso deverá ser também pontuado 3.12.3 Pessoas parecem disfarçadas*). NB: Se objetos não humanos, situações ou eventos estão também incluídos neste sentimento, pontuar 5.6, Experiências jamais vu.

- "Conheço-lhe o nome e tudo sobre ela, e ainda assim ela aparecia-me como estranha, irreal, como uma estátua... Eu estava na presença de uma estranha.” [18] (pontuar também 3.9, Despersonalização dos outros)

\subsubsection{As pessoas parecem disfarçadas *}

As pessoas parecem estar de algum modo a esconder ou a cobrir a sua verdadeira identidade. O sujeito pode experienciar este item em combinação com (e especialmente como explicação para) a despersonalização e alterações na familiaridade. O sujeito pode falar de pessoas "andando incógnitas" ou de algum modo "pretendendo" ser alguém que não são.

\subsubsection{As pessoas parecem estranhamente ameaçadoras*}

Há algo na aparência das pessoas que é qualitativamente estranho/perturbador, parecendo indicar que os outros são de alguma forma ameaçadores. NB: Pode ser combinado com os itens 3.4.2, Sentimento de paranoia social ou ansiedade social*, e 3.4.3, Desconfiança pervasiva dos outros.

- "Ele apercebeu-se de um comportamento estranho num familiar que o fez sentir-se estranho... Um transeunte olhou-o também com um olhar penetrante, poderia ser um detetive." [14] 
3.12.5 Mudanças gerais/inespecíficas na aparência física de outros (= BS C.2.3.5) O sujeito identifica as características físicas, tais como o rosto e corpo, de outras pessoas como alterados, distorcidas, deformadas, ou estranhamente nãonaturais. Por exemplo, a cor ou a aparência do rosto, dos olhos, ou do cabelo podem parecer alteradas, embora não necessariamente de uma forma literal.

- "As pessoas pareciam demasiado gordas ou magras, de alguma forma desfigurada e não como pareceriam normalmente." [1]

- "Os rostos [das pessoas] rearranjam-se por vezes se olhassem para elas demasiado tempo e eu perco o fio ao que estão a dizer. Tornam-se muito caleidoscópicos. E os rostos começam a rearranjar-se:" [Conteúdo não publicado]

• "Os olhos do meu marido mudaram de um azul brilhante para um castanho escuro." [1]

3.13 As pessoas parecem comunicar algo especial ou incomum (para lá do óbvio) $(\sim \mathrm{BS}$ C.1.17)

Refere-se ao sentimento de que as outras pessoas estão a insinuar ou transmitir alguma mensagem especial, muitas vezes dirigida para, ou destinada ao sujeito. $\mathrm{O}$ que as pessoas querem dizer pode ser bastante distante de que elas realmente estão a dizer. O sujeito pode ou não ser capaz de identificar o conteúdo ou o significado da mensagem.

\subsubsection{Significado paranoide*}

A comunicação especial é experienciada como indicando desagrado, crítica, acusação, intenção malévola, ou como conspirativa contra o sujeito.

- "Estavam todos a usar jogos de linguagem... de forma a perseguirem-me... as pessoas usavam gestos, acenos e sorrisos para comunicarem entre si que eu era o alvo destinado" [49]

- "Ela perguntou-me se eu os queria para sábado. O que ela queria dizer é que eu era uma prostituta." [47]

\subsubsection{Significado grandioso*}

A comunicação especial é experienciada como uma indicação de poderes incomuns do sujeito ou de superioridade sobre os outros. 
- "Eu ouvia as pessoas dizerem-me [que eu estava ou adiantado ou atrasado], pessoas em multidões, e tinha imensos delírios sobre isso: pensava que eu deveria parar o tempo, que esse era o meu objetivo." [Dados não publicados]

\subsubsection{Significado metafísico}

A comunicação especial é experienciada como uma indicação de uma mudança no tecido do universo, como uma aproximação do fim do mundo ou qualquer outro significado metafísico.

- O que as outras pessoas diziam significava de alguma forma "... que o mundo estava a chegar ao fim e disto resultava que o mundo se referia constantemente, embora de forma codificada, ao seu colapso." [42] (também pontuar/marcar 5.16, Experiências de fim do mundo)

\subsubsection{Significado instável/desconhecido}

A comunicação de uma pessoa ou pessoas tem um significado especial para o sujeito, mas este é incapaz de dizer qual é.

- "Eu não conseguia entender o que qualquer pessoa queria realmente me dizer, então quando falavam comigo, de alguma forma... ficava assoberbado por todo o tipo de mensagens secretas que me tentavam enviar." (Dados não publicados)

\subsection{Respostas anômalas (em atitudes ou comportamentos) para com os outros}

O sujeito tem consciência de agir - ou de se sentir compelido a agir - de forma não usual ou estranha quando se relaciona com outras pessoas, como, retirarse, revoltar-se, conformar-se, adquirir uma postura de observação, etc., muitas vezes associando-se a ansiedade profunda, ameaça interpessoal ou de perplexidade. Os subtipos podem ter uma qualidade involuntária/automática (eventualmente catatônica) ou adquirir uma natureza intencional/ativa ("antagonômica" [41]); pode ser útil aos entrevistadores investigar essa natureza.

\subsubsection{Remoção ativa*}

O sujeito sente-se obrigado ou inclinado a retirar-se da presença das outras pessoas, por exemplo, fechando-se no seu quarto ou em casa, por sentir ansiedade, medo ou desconforto nas relações interpessoais. 
- "Eu tento manter as coisas a uma certa distância, pois sinto-me demasiado implicado no destino dos outros, não consigo lidar com isso. Evito qualquer conversa, porque me excitam demasiado. Se alguém vier em casa visitar-nos, eu removo-me. "[1]

\subsubsection{Comportamento em oposição/rebelde*}

O sujeito sente-se obrigado a opor-se ou a resistir aos outros. Isso pode incluir recusar-se a cooperar com o entrevistador (oposição), afastar-se deste enquanto fala (aversão) ou fazer o oposto do que é pedido (negativismo).

• "Eu rejeito a tendência natural de me identificar com o que os outros dizem." [41]

\subsubsection{Desinibição social*}

O sujeito tem consciência de agir de uma forma que de algum modo demonstra indiferença para com as normas sociais - quer por desrespeito ativo ou por ignorar expectativas sociais.

- "As pessoas compram um bilhete para entrar no comboio - essa é a regra. Mas esta regra é para eles, não para mim." [41]

\subsubsection{Desejo compulsivo de harmonia interpessoal*}

O sujeito sente que as suas relações devem ser permanentemente e completamente harmoniosas e benignas, totalmente desprovidas de conflitos. Por exemplo, o sujeito pode descrever sentir-se "incapaz de discordar" ou como se tivesse de estar sempre "de acordo" com os outros.

\subsubsection{Compliance extrema}

O sujeito está ciente de copiar os comportamentos dos outros ou de agir de acordo com o que é esperado de forma tão extrema, que sugere algo mais do que mera conformidade social. $\mathrm{O}$ sujeito pode descrever esta experiência como obediência "automática", ou cumprimento quase "mecânico" com os pedidos do interlocutor, ou como uma espécie de ecopraxia (imitando o movimento do outro); o entrevistador deverá registrar estes detalhes.

3.14.6 Compulsão para palhaçada/entretenimento dos outros* 
O sujeito sente como se tivesse de "agir como um tolo", de se comportar como um palhaço ou "fazer de brincalhão" [50], quando está perto dos outros, talvez em resposta à ansiedade, ou talvez como expressão de desdém/superioridade. Este comportamento parece forçado, automático ou extremo para além de um desejo mais mundano de ser divertido.

\section{Linguagem}

Descrição Geral: Os dez itens no Domínio 4 referem-se a anomalias na experiência da linguagem, seja do próprio sujeito ou das outras pessoas. Aqui o foco é na experiência subjetiva das palavras e do significado, do fluxo da linguagem, da gramática, dos conceitos verbais e dos problemas de expressão verbal (não nos comportamentos verbais ou estruturas linguísticas implícitas). As alterações neste domínio podem ser particularmente difíceis de serem percebidas pelos próprios indivíduos. Os entrevistadores podem ter a necessidade de formular as perguntas de várias maneiras, parafraseando as questões iniciais de forma geral e só depois questionando sobre aspectos específicos. Por exemplo, antes de inquirir sobre o item 4.4, Escolha não convencional de palavras, gramática, tom ou discurso críptico/enigmático pode perguntar: "Já sentiu que desejava usar a linguagem de forma estranha ou incomum?" ou "Algum dia ficou incomodado pela linguagem, ou com desejo de falar/usar a linguagem de forma diferente das outras pessoas?".

Durante a entrevista, os entrevistadores podem observar certas anomalias de discurso que não eram reconhecidas ou assumidas pelos sujeitos quando questionados em um item relevante da EAWE. Neste caso, deve-se considerar perguntar gentilmente aos indivíduos se têm noção destas anomalias, mas apenas ao final da entrevista EAWE (para não perturbar o rapport). Se o sujeito continuar a negar estas anomalias, apesar de as manifestar, os entrevistadores devem registrar este comportamento, mas não devem cotar na EAWE.

4.1 Disrupções básicas da compreensão verbal standard ( BS C.1.6) 
$\mathrm{O}$ sujeito tem dificuldade em compreender a linguagem escrita ou falada, incluindo os significados de palavras, frases ou sequências de frases. Pode ocorrer enquanto está lendo e ouvindo os outros, mas também quando fala/escreve.

\subsubsection{Dissociação entre o som e o significado}

O sujeito tem dificuldade em colocar sons e palavras em conjunto com os seus significados (juntar a fonética com a semântica)

•"Mas o que é um comboio? É uma palavra. A palavra não tem nada a ver com a coisa sólida que é um comboio." [22]

- "Eu dizia 'cadeira, jarro, mesa, é uma cadeira.' Mas as palavras ecoavam de forma vazia, privadas de todo o seu significado; parecia que tinha deixado o objeto a que correspondia, que se tinha divorciado dele... agora um nome, sem um sentido prático, um envelope vazio de conteúdo. Não fui capaz de os juntar novamente... " [18]

\subsubsection{Distração por possibilidades semânticas}

O sujeito pensa sobre todos os significados possíveis de uma determinada palavra ou frase ou tem dificuldade em determinar o sentido em que uma palavra foi usada, podendo levar a que perca a noção do que está a ouvir, ler ou dizer.

- "... tudo o que eu lia tinha um grande número de associações possíveis... todas as coisas pareciam chamar a minha atenção e aí começava, bang-bang-bang, assim, subitamente surgiam um grande número de associações ligadas às coisas, a um ponto que era difícil lidar com todas elas e não era capaz de ler." [22]

\subsubsection{Distração por palavras individuais}

O sujeito experiencia uma tendência de "emperrar" ou se focalizar em palavras individuais ou frases e assim perder o sentido e intenção globais da frase ou parágrafo.

- "Ao ler, questiono-me muitas vezes sobre palavras comuns e tenho de pensar sobre o seu significado." [1]

4.1.4 Dificuldade inespecífica de compreensão

O sujeito tem dificuldade em entender ao ler ou ouvir.

• "Cada vez mais, apenas lia as linhas sem compreender o que significavam." [1] 
• "Quando as pessoas falam, tenho de pensar no que significam as palavras." [12]

- "Às vezes, quando as pessoas falam comigo, fico com a cabeça sobrecarregada. É demasiado para apreender de uma única vez... são só palavras no ar a não ser que consigas compreendê-lo a partir das suas caras." [12]

\subsection{Dificuldade em compreender aspectos emocionais/expressivos do discurso*}

O sujeito experiencia dificuldade no reconhecimento nas entoações emocionais no discurso dos outros, o que pode resultar em falhas na compreensão das nuances emocionais na comunicação.

- "Eu ouço as pessoas falar, mas não compreendo o significado das palavras. As vozes eram metálicas, sem calor ou cor." [18]

4.3 Alterações específicas na sensação padrão ou significado das palavras ( BS C.1.6)

O sujeito experiencia, e pode até usar, palavras de formas anômalas, quer focalizando-se nas qualidades físicas das palavras, atribuindo-lhes novos significados, vendo as palavras como absurdas ou arbitrárias, ou até vendo as palavras como "vivas" (com comportamentos particulares espontâneos). NB: Ao contrário de 4.1, Disrupções básicas da compreensão verbal standard, e em 4.2, Dificuldade em compreender aspectos emocionais/expressivos do discurso, no item 4.3 não é necessária existir alteração da compreensão, embora seja também possível.

\subsubsection{Concentração no som ou na aparência de palavras ou frases *}

$\mathrm{O}$ sujeito experiencia uma tendência a estar estranhamente consciente da forma elou a aparência física da linguagem escrita, ou da qualidade do som das palavras. NB: Se isso perturba o significado, deve ser também cotado 4.1.1, Dissociação entre som e significado.

- "As palavras têm suas próprias texturas, que podem não ser as mesmas texturas das coisas que eles representam." [22]

4.3.2 Determinação semântica não convencional, por meio de novos significantes ou de fragmentos de palavras 
O sujeito considera o significado determinado pelo som ou pelo aspecto das palavras, ou por partes das palavras (fonemas ou sílabas) mais do que pelo significado convencional, ou pode focalizar-se em partes das palavras ao invés da unidade de significação habitual.

- "MAMMA para mim significava que desde o início estamos nós dois (M), depois estamos sozinhos (A), depois estamos juntos por um longo tempo (MM), mas no final nós ficamos sozinhos novamente (A). Letra após letra, eu queria perceber se a sequência das letras correspondia ao seu significado original". [51]

- "Contentamento? Bem, contentamento, bem a palavra contentamento, ter um livro talvez ... mas quando você chega à palavra (men) 'homens' fica a pensar porque se deve contentar com um homem na sua vida e quando chega à letra $\mathrm{T}$ fica a pensar se deve mesmo ficar contente com ter chá para si mesmo ou ficar contente com tê-lo num grupo ou assim." [22]

\subsubsection{As palavras parecem arbitrárias/absurdas}

O sujeito está particularmente consciente da arbitrariedade das palavras, às vezes ao ponto de se recusar ou não ser capaz de aceitar a sua utilização padrão ou considerar completamente o significado da comunicação.

- "Eu não entendo por que isto tem que ser chamado de uma mesa, e se lá fora está sol porque é que nós temos que dizer que está um bom dia." [41]

4.3.4 As palavras ou a linguagem parecem vivas, quase físicas, ou estranhamente poderosas

As palavras ou frases são experienciadas como tendo "vida própria" ou como se tendo tornado estranhamente "objetificadas". O sujeito pode sentir que a linguagem se determina a si mesma ou que a linguagem ou as palavras são "objetos sagrados, imbuídos de um poder mágico." [52]

- "Palavras respiram, elas piscam-me o olho; são capazes de transformar o mundo e a elas mesmas." [53]

- "Uma destacou-se da frase... Essa palavra tornou-se como algo material, quase uma "coisa" para mim, ou uma imagem à minha frente." [51]

\subsubsection{Linguagem com referencial egocêntrico ( BS C.1.17)}


Palavras específicas ou outros itens linguísticos são experienciados como tendo uma referência especial ao sujeito. A questão aqui não é o conteúdo de uma declaração particular ou mensagem escrita, mas um sentido mais fundamental que uma palavra ou palavras (ou algo inerente ao próprio meio linguístico) diz respeito de alguma forma ao sujeito.

- "Qualquer palavra poderia ser considerada como se estando a referir a mim, até mesmo se fossem referências distantes, era interpretada dessa maneira ..." Por exemplo a palavra "América" poderia ser entendida como 'Am Erica', isto é, uma referência codificada a alguém que pensa que é uma mulher. Então eu consideraria que isso significa que as pessoas em geral consideravam que essa palavra dizia respeito a mim..." [49]

4.4 Escolha não convencional de palavras, gramática, tom ou discurso crípticolenigmático ( BS C.1.7, EASE 1.17)

O sujeito usa, esconde ou organiza palavras de formas estranhas o que impede a compreensão pelos outros. Isto pode ser voluntário ou quase-voluntário e o entrevistador deve registrar os detalhes.

\subsubsection{Discurso críptico, telegráfico ou agramatical}

O sujeito tem consciência de adotar, decidir usar ou apercebe-se que está a usar um discurso que é telegráfico (omitindo várias palavras, talvez até crípticas para os outros) ou por vezes faltando-lhe a estrutura gramatical habitual. O sujeito pode descrever falar intencionalmente de forma sem sentido ("nonsense") ou entrar no seu "modo schizo de falar" de forma mais ou menos voluntária só para obscurecer o significado ou testar os outros ao seu redor. [22]

\subsubsection{Palavras "stock"}

O sujeito declara que fixar-se em uma palavra convencional para se referir a vários significados para além do que habitualmente a palavra significaria. Pode fazer com que o discurso ou a escrita fiquem cheios de uma ou mais palavras tornando-se exagerados ou empobrecidos.

- "Assim o paciente usava a palavra navio para quase todos os objetos chamando por exemplo a um relógio 'navio de tempo'. " [24] 
4.4.3 Invenção de palavras (neologismos) ou uso não convencional da linguagem O sujeito está ciente de usar palavras inventadas, ou de usar a semântica de palavras existentes de forma idiossincrática. Pode haver um desejo de brincar com os conceitos, o desejo de criar uma linguagem privada ou a incapacidade de encontrar as palavras certas; o entrevistador deve registrar os detalhes.

- "Se não consigo encontrar a palavra apropriada para descrever o fluir das minhas ideias, procuro libertar-me por palavras inventadas por mim, por exemplo decido-me por wuttas para pombas." [50]

- "Eu construí palavras que não existiam, porque as minhas experiências precisavam de algo fosse mais além [da linguagem comum]." [51]

\subsubsection{Discurso grandioso e maneirismos}

$\mathrm{O}$ sujeito declara experienciar a linguagem como um meio de comunicação altamente civilizado ou teatral - talvez de maneira excessivamente artificial ou formal - e descreve que exagera estas qualidades no seu próprio discurso ou pronúncia. [24]

- Um paciente "expressava trivialidades em frases altivas de forma afetada como se estivesse a tratar dos temas mais importantes da humanidade." [54]

\subsection{Perturbação da Fluência ( BS C.1.7, EASE 1.17)}

O sujeito está consciente de lhe ser difícil expressar-se, devido a uma incapacidade ou lentificação da fluência do discurso, precisão ou disponibilidade, ou inadequação na sua expressão verbal (opondo-se a um problema de inefabilidade, como no item 4.9.1 Linguagem inadequada para exprimir experiências anômalas*). $O$ sujeito sente uma diminuição da capacidade de usar a linguagem como um meio de transmitir um significado, e pode estar especialmente atento ao meio linguístico.

\subsubsection{Indisponibilidade de palavras}

O sujeito descreve a sensação de que não é capaz de encontrar as palavras certas para descrever a sua experiência. NB: Contrariamente ao 4.9 Outras experiências de inadequação da linguagem que envolvem uma sensação de inefabilidade, aqui 
a pessoa sente que não pode encontrar ou lembrar-se das palavras certas, e não que estas não existem.

4.5.2 Pensamentos desorganizados ou desfocados precedem e impedem a expressão verbal.

O sujeito é incapaz de se expressar adequadamente pois tem dificuldade em focalizar-se num tema em particular ou numa linha de pensamento - como se os pensamentos fossem demasiados em números ou desorganizados para permitir sua existência ou tradução em expressões verbais lineares.

• "Os pensamentos eram tantos que eu não consegui falar." [55]

4.5.3 Discordância geral entre a expressão pretendida e o que foi expresso (=BS A.7.2, =EASE 1.16).

"Experiência subjetiva de não ser capaz de se expressar de acordo com os sentimentos atuais ou emoções (ou pensamentos). O sujeito experiencia o discurso como não estando de acordo, ou congruente, com o que ele sente (ou pensa); a sua expressividade é sentida como desfigurada e distorcida e em parte fora do seu controle." [2]

- "É como se eu não pudesse evitar expressar coisas duma forma que dá uma ideia diferente do que queria e nem sequer me apercebo disso." (Dados não publicados)

- "Isso leva-me a tentar exprimir algo sério, mas durante essa expressão fica tudo tão confuso que certos detalhes ficam distorcidos; com a alteração destes detalhes parece que já não é assim tão sério.” (Dados não publicados)

- "Pensei que a minha linguagem estava errada. Acreditava que ninguém podia compreender o que eu dizia. Eu não podia compreender o que eu dizia. Só saíam barulhos de timbre elevado." [33]

\subsection{Perturbação da relevância}

O sujeito está consciente de ter problemas para manter o fio condutor do pensamento quando fala ou escreve.

\subsubsection{Descarrilamento *}

O sujeito tem consciência da tendência em esquecer ou perder o fio condutor do pensamento quando fala ou escreve, de forma que a expressão verbal carece de 
coerência geral (mostrando um "afrouxamento associativo" mais extremo do que as variações normais no fluxo da linguagem). O sujeito está consciente de ser distraído pela intrusão de associações que "levam para outro pensamento" ou "mudam de assunto", de ter dificuldade em decidir o que é relevante, ou talvez de apenas não ter muita percepção da direção do que estava a pensar ou a falar. (o entrevistador deve procurar distinguir estas formas).

- "Os meus pensamentos ficam todos descoordenados. Começo a pensar ou a falar sobre alguma coisa, mas nunca chego lá... as pessoas que me ouvem ficam mais confusas que eu." [12]

- "Muitas vezes não sei que detalhes incluir e posso mesmo lembrar-me dum monte de coisas irrelevantes para dizer porque não faço ideia do que é relevante." (Dados não publicados)

\subsubsection{Respostas tangenciais}

O sujeito relata ter consciência de responder às perguntas ou declarações dos outros de uma forma oblíqua, "irrelevante", ou fora do contexto. Falta-lhe a relevância do comentário ou da pergunta da outra pessoa (em vez de a coerência contínua da própria língua, uma vez em andamento).

\subsection{Perturbação do envolvimento / objetivo linguístico}

O sujeito está consciente de adoptar (ou manifestar-se por meio de) uma postura ou estilo de expressão estranhos - faltando-lhe o sentido habitual de envolvimento emocional e volitivo.

\subsubsection{Aprosódia (falta de entoação emocional) * ( BS A.7.2)}

O sujeito vivencia o seu próprio discurso como carecendo de entoação emocional, descrevendo-o como "aplanado", "sem vida” ou "morto", e pode expressar ainda perda da capacidade ou do desejo de transmitir os seus sentimentos ou emoções através da linguagem.

\subsubsection{Ecolalia ( BS C.3.1)}


O sujeito refere-se a uma necessidade ou tendência automática a repetir como um "eco" ou a acompanhar o discurso do interlocutor de alguma forma.

\subsubsection{Discurso como autônomo ( BS C.3.1)}

Sensação que o seu discurso (ou escrita) decorre de forma independente de si mesmo, possivelmente por controle externo. Pode resultar em pressão do discurso ou até na perda da coerência à medida que significados se tornam cada vez mais confusos.

- "Um paciente ... diria sobre o seu discurso 'alguém está a controlar-me', que este 'sai por si só', ou que 'eu estou a ser forçado a falar."' [22]

\subsection{Experiências anômalas do abstrato e do concreto}

Dificuldade em aceitar ou compreender conceitos abstratos ou gerais, relação errônea entre abstrato e concreto, foco acentuado no que é altamente abstrato/geral ou então completamente concreto/específico.

4.8.1 Dificuldade ou antipatia para com conceitos abstratos ou gerais ( BS C.1.16)

Sujeito considera conceitos ou símbolos gerais ou abstratos (por exemplo, aquilo que é expresso em aforismos ou provérbios) como sendo arbitrário, absurdo, ou simplesmente difícil de entender. Pode envolver uma tendência para descrever e compreender as coisas literalmente, para enfatizar casos individuais, ou se concentrar em experiências sensoriais imediatas ou em sentimentos ou sensações interiores únicas e inefáveis.

- "Agora tenho dificuldades para compreender o significado simbólico de provérbios e fábulas, coisa que eu não tinha antes." [1]

• "Não consigo mais reconhecer se um determinado objeto ou evento é ou não apenas um símbolo ou metáfora para algo mais geral, abstrato ou filosófico.” [1]

4.8.2 $\mathrm{O}$ abstrato é expresso em terminologia estranhamente concreta ( BS C.1.16) O sujeito está ciente de usar a linguagem extraordinariamente concreta para descrever conceitos abstratos, como por exemplo, descreve o tempo como uma "porta" ou raiva como "flechas" (entrevistador deve registrar o exemplo dado.) 
NB: Se essa tradução concreta for perceptual em vez de linguística, deve ser considerado o item 5.9.1, Instanciação física ou literal de significado abstrato.

4.8.3 Significados específicos/concretos expressos em terminologia estranhamente abstrata ou geral

(O entrevistador deve registrar o exemplo) NB: Se esta coocorre com uma categorização estranha, ver também 5.9.2, Anomalias na classificação.

- "Refere-se a uma vela como 'um objeto de iluminação noturna' e a uma pá como 'um utensílio doméstico."' [22]

\subsubsection{Discurso vago/hiperabstrato.}

Consciência de falar tendencialmente de uma maneira que pode soar (talvez. especialmente aos outros) excessivamente abstrata, geral, ou vaga a ponto de ser difícil de perceber ou lembrar (semelhante ao que em psicopatologia descritiva se chama "pobreza do pensamento").

- "Falo e parece que não digo nada e em seguida descubro que estive a falar sobre tantos assuntos existenciais, mas não me lembro de nada do que disse." [56]

4.9 Outras experiências da inadequação da linguagem que envolvem uma sensação de inefabilidade (pode incluir a tentação de permanecer em silêncio)

$\mathrm{O}$ sujeito experiencia a linguagem como inadequada ou profundamente inautêntica, incapaz de descrever ou expressar o que realmente lhe importa. Pode envolver a inclinação de permanecer em silêncio, pelo menos em determinados assuntos.

4.9.1 Linguagem inadequada para expressar experiências anômalas * O sujeito sente que a linguagem é incapaz de captar suas experiências, devido à natureza estranha destas experiências. Pode estar relacionada com a tendência do sujeito para se centrar no inefável (por exemplo, as suas experiências serem demasiado universais, abrangentes ou abstratas, ou então demasiado minuciosas, específicos ou concretos, para serem encapsuladas em palavras). NB: O sujeito deve mencionar claramente a natureza incomum ou estranha das suas experiências. 
- "Há coisas que vivi que saíram totalmente do âmbito de tudo o que tinha previamente experienciado, mas que não sou capaz de descrever (ou até mesmo começar a descrevêlas); não há nenhuma maneira de expressá-las. "(dados não publicados)

- "Reforço que é extremamente difícil descrever essas mudanças em palavras, porque trata-se de questões que carecem quaisquer analogias na experiência humana ..." [57]

\subsubsection{Sentimento geral da inadequação da linguagem}

O sujeito sente como se a expressão linguística fosse - em natureza, de alguma forma inútil, impossível ou profundamente inadequada ou inautêntica. Pode haver uma sensação de evitar o mundo linguístico ou simbólico, o que a linguagem, pela sua natureza seja um meio incapaz para uma comunicação verdadeira ou compreensão mútua, especificamente pela natureza demasiado abstrata, generalizadora ou convencional dos conceitos. O sujeito pode sentir que precisa/deseja evitar falar ou escrever ou usar muitos detalhes de forma a expressar adequadamente as suas experiências. NB: Ao contrário de subtipo 1, aqui não existe qualquer menção à natureza incomum das experiências do sujeito. • "Eu estou bloqueado pelas limitações das palavras inadequadas...", disse um paciente, explicando o seu silêncio como devido à uma "inadequação em usar a linguagem para expressar o que vem de tão fundo dentro de mim." [22]

- "Acho que não posso... aceitar o quão inadequada é a linguagem abstrata ou geral para capturar ou comunicar plenamente o que quero (ou sinto que preciso) pensar ou expressar." (Dados não publicados)

- "Eu entro em tantos detalhes porque eu tendo a considerar a linguagem normal / simples como inadequada para descrever a complexidade da minha experiência." (Dados não publicados)

• "Tudo é demasiado subtil. Há subtilezas que não é possível expressar. "[37]

\subsection{Sentimento de alienação nas descrições de si próprio}

O sujeito experiencia um sentimento de profunda distância ou desconexão quando se descreve a si mesmo ou suas experiências, como se estivesse falando de outra pessoa. Isto não é meramente devido a um contraste entre as experiências que estão a ser recordadas e o seu estado atual, parece antes envolver uma dificuldade em identificar-se com a pessoa que está a ser representada (embora seja ele próprio). 


\section{Atmosfera (sentimentos anômalos de alterações da realidade, familiaridade,}

significação, relações causais, intensidade, tom emocional)

Descrição Geral: Os 17 itens do Domínio 5 referem-se a anomalias na experiência da qualidade global, sentimento ou organização do mundo externo. Aqui estamos interessados em qualidades subtis, pervasivas ou inquietantes que pertençam ao horizonte "geral", ambiente, estrutura, humor ou atmosfera de todo o mundo-vivido - como as coisas, em geral, parecem ao sujeito. Estes componentes estão por todo o lado e em lado nenhum; são difíceis de isolar ou descrever por sua natureza tão abrangente. Não é necessário que absolutamente todos os aspectos da experiência do sujeito estejam afetados por estas alterações; a ênfase, contudo, está na qualidade pervasiva ou semelhante ao humor das mudanças, que pode estar fixada em certas coisas ou pode infundir a totalidade do mundo-vivido.

\subsection{Desrealização do mundo (BS C.2.11.1, EASE 2.5)}

"Uma mudança na experiência do ambiente: o mundo circundante parece de alguma forma transformado, irreal, e estranho, e pode ser comparado à visualização de um filme." [2]

"Desrealização" é um termo vasto e ambíguo; aqui será empregue apenas com respeito a experiências que envolvam uma diminuição nos sentidos de imediatismo, realidade, utilidade, pertinência, autenticidade, vitalidade ou dinamismo. (Experiências de hiper-realismo ou de solipsismo são classificadas em outros itens abaixo.) É algo distinto de uma distorção da realidade no sentido das alucinações ou delírios: não se trata de uma falha em reconhecer a identidade de pessoas ou coisas, mas da experiência de uma mudança sutil, ainda que pervasiva, no sentir ou na realidade sentida do mundo. A mudança ocorre sem perda da noção do real/insight/consciência crítica das suas experiências. Deve ser explicitado/pontuado caso ocorra depois ou associado a um ataque de pânico.

5.1.1 Afastamento ou barreira (sensação de placa de vidro) * ( EASE 2.4.2) 
Sentir-se como que amputado do mundo, como se o mundo estivesse distante ou para lá de uma barreira transparente.

• "Tudo surge como através de um véu; como se eu ouvisse tudo através de uma parede." [14]

- "Não sinto as coisas como reais. Há algo entre mim, as coisas e as pessoas à minha volta; algo como uma parede de vidro entre mim e tudo o resto." [58]

\subsubsection{Intensidade ou substancialidade diminuídas*}

$\mathrm{O}$ sujeito experiencia uma diminuição geral na intensidade ou na qualidade substancial do mundo, não específica a nenhum sentido/modo de percepção. $\mathrm{O}$ sujeito pode descrever a realidade ou a existência de tudo como estando de algum modo "atenuada", "diminuida", "aplanada" ou "oca". (Pode, obviamente, sobrepor-se a subtipos anteriores.)

• O sujeito descreve a sensação de um mundo "fino como plástico", "imaterial", ou como "imagens flutuantes", "conchas sem nada dentro" ou "uma casa de cartão," [21] ou talvez como "estranho, bidimensional" ou " apenas silhuetas." [2]

\subsubsection{Perda de vitalidade/Inanimação (Deanimation) *}

Sentimento geral de que as coisas - por exemplo, uma árvore ou uma paisagem parecem inanimadas, ou mais despidas de vida e mecânicas do que normalmente estariam. NB: Se ocorre apenas com pessoas, ver item 3.9, Despersonalização dos outros, acima.

- Um paciente descreveu o pátio da escola como "ilimitado, irreal, mecânico e sem sentido." [18]

• "... Coisas... mais artificiais, separadas umas das outras, irreais, sem vida." [18] (também marcar/pontuar 5.1.4, Falsidade)

\subsubsection{Falsidade (= EASE 5.5)}

Tudo parece, de algum modo, falso, fraudulento ou postiço, ilusório, ou uma "imitação" [50], talvez teatral, como desenhos animados ou um mero simulacro. O mundo pode ser experienciado como artificial ou como meramente "virtual", lembrando filmes como "The Truman Show" ou "The Matrix".

- Um paciente russo no hospício Burghölzli, na Suíça, afirmava que "uma cópia idêntica, o 'Burghölzli Russo', tinha sido erguida." [50] 
- "Quando criança, ela sentia que 'o mundo inteiro tinha construído apenas para ela ', como uma cena." [2]

- "Não pode imaginar como é que é saber que tudo é simulado. Jantar - mesmo na casa da minha avó! - parece falso!" [59]

\subsubsection{Perda da qualidade instigante/estimulante *}

O sujeito sente-se como se os objetos não tivessem nenhuma utilidade ou apelo à ação para ele (apesar de ainda poder reconhecer o seu sentido usual ou significado prático). Por exemplo, ele pode não ter nenhuma dificuldade em reconhecer algo como um martelo (ou seja, não se apresenta para ele como uma mera forma geométrica), mas é incapaz de registrar ou conceber a sua utilização prática ou relevância para si próprio. NB: Pode sobrepor-se ou acompanhar 5.2, Perda de affordances (significado prático), embora também possa ocorrer com affordances intactas.

• "... cada vez mais, apesar dos meus esforços, perdi o sentido das coisas práticas." [18]

\subsubsection{Caráter estático, imobilidade ou intelectualismo mórbido}

O mundo é experienciado como se estivesse dominado por qualidades ou aspectos fixos, estáticos, geométricos ou puramente racionais, enquanto as ações, processos dinâmicos e aspectos flexíveis ou maleáveis perdem importância (inclui o "geometrismo mórbido" de Minkowski [38]).

- "Gosto de objetos imóveis, caixas e parafusos, coisas que estão sempre lá, que nunca mudam." [60]

- As pessoas são percebidas como "truncadas", como "linhas perpendiculares", "destituídas da sua carne" ou como tendo uma "cabeça trapezoide." [21]

• "[Um paciente] vivia por ideias e via as pessoas como objetos impessoais." [60] (pontuar também 3.9.3, As pessoas parecem mecânicas)

\subsubsection{Desrealização inespecífica/outra *}

O sujeito descreve as coisas como estranhas ou desrealizadas, sem ser capaz de especificar como isso acontece, ou as suas descrições não se encaixam em nenhum dos subtipos anteriores. 
- " O paciente experiencia as outras pessoas como robôs e tudo como um grande pote de moléculas e começa então a perguntar-se se o mundo será real." [2] (também pontuar 3.9.3, As pessoas parecem mecânicas)

- "Todos os objetos parecem tão novos e surpreendentes que digo os seus nomes para mim mesmo e toco-os várias vezes para me convencer de que são reais. Bato o pé no chão e continuo com uma sensação de irrealidade." [14] (marcar também 5.6, Experiências jamais vu).

\subsection{Perda de affordances (significado prático)}

Os significados práticos e convencionais dos objetos e acontecimentos desaparecem, substituídos por um modo de percepção puramente geométrico, visual ou até mesmo estético. NB: Pode ou não coincidir com os subtipos de Desrealização do mundo (item 5.1), especialmente 5.1.5, Perda da qualidade instigante/estimulante.

- "Os objetos são como adornos de palco, colocados aqui e ali, cubos geométricos sem significado." [18] (também marcar/pontuar 5.1.4, Falsidade; considerar 5.1.5, Perda da qualidade instigante/estimulante)

- "Quando, por exemplo, olhava para uma cadeira ou um jarro, não pensava na sua utilidade ou função - um jarro não como algo que contém água e leite, uma cadeira não como algo para se sentar - mas como tendo perdido os seus nomes, as suas funções e significados..." [18] (Considerar também 5.1.5, Perda da qualidade instigante/estimulante.)

- "Um jardineiro, a 50 metros, varrendo um caminho é 'uma longa faixa com algo movendo-se para trás e para a frente'.” [15]

\subsection{As coisas inanimadas parecem vivas ou intencionais *}

Os objetos e coisas não-vivos/inanimados parecem de alguma forma vivos, ou como se emitissem ou estivessem infundidos de uma energia especial que os faz parecer autônomos e com vida. Os objetos podem até parecer expressar ou comunicar algum significado (normalmente ao sujeito) de uma forma animada ou semelhante à humana.

- "Obstáculos, cadeiras, edifícios ganhavam vida própria. Pareciam fazer gestos ameaçadores, ter um caráter animista." [13] 
O sujeito experiencia um aumento geral na intensidade do mundo, não específico de nenhum sentido ou modo de percepção particular. Os objetos e as coisas parecem mais impressionantes do que o habitual, de algum modo mais intensos e exigentes da atenção do sujeito.

- "Assim como o mundo perceptual pode ser experienciado como algo estranho ou morto, também o pode ser como algo inteiramente fresco e de assoberbante beleza." [14]

- "O comportamento do cão causou uma forte impressão em mim; era tão selvagem, descontrolado, tão cheio de natureza pura, selvagem e instintiva... toda a paisagem era tão autêntica, tão primordialmente natural, tudo era tão comovente que senti uma imensa felicidade." [2]

\subsection{Experiências déjà vu (= BS C.2.11.3)}

O sujeito diz experienciar uma sensação anormal de familiaridade, de tal forma que coisas, situações ou acontecimentos não previamente experienciados parecem, apesar disso, familiares. Muitas vezes sentida como mais intensa ou significativa do que a experiência déjà $v u$ quotidiana. NB: Se a experiência envolve pessoas, marcar/pontuar também 3.12.1, As pessoas parecem familiares de um modo estranho.

- "O mesmo visitante, com exatamente as mesmas roupas, estava aqui há um ano e disse as mesmas coisas." [50] (Considerar também 3.12.1, As pessoas parecem familiares de um modo estranho)

• "Quando ouvia notícias sentia que já as tinha ouvido antes." [28]

• "Sentia que já tinha feito essas coisas." [28]

\subsection{Experiências jamais vu}

O sujeito percebe um objeto, cena, situação ou conceito encontrados anteriormente (que ele sabe já ter encontrado antes) como se não tivesse experiência prévia do mesmo, como se o estivesse a ver pela primeira vez, como desconhecido ou até incompreensível. [14] NB: Se a experiência envolve pessoas, marcar/pontuar também 3.12.2, As pessoas parecem não familiares de um modo estranho. Comparar com 2.4.2, Surpresa constante.

- "Sabia que era o meu quarto, mas sentia-me como se nunca tivesse posto os olhos nele antes." [15] 
• "É como se eu tivesse visitado um lugar pela primeira vez..." [33]

- "Eu sofro de uma diminuição da memória, ou algo parecido: há muitos conceitos que, de repente, parecem tão estranhos para mim. Tenho de me habituar a eles novamente de cada vez. Eles parecem novos para mim, apesar de não me ter exatamente esquecido deles. São só tão fora do normal." [37]

\subsection{Perplexidade}

Um sentimento profundo e perturbador de estar perplexo ou confuso com o sentido geral da realidade.

5.7.1 Confusão de domínios experienciais (=BS C.1.15, EASE 1.10).

O sujeito experiencia uma fusão ou confusão entre diferentes domínios, universos ou modalidades experienciais; isto é: dificuldade em distinguir entre, por exemplo, percepção e imaginação, memória e imaginação ou memória e percepção.

- "Quando falo consigo [o terapeuta dele] não sei se estou a ter uma alucinação ou uma fantasia sobre uma memória ou uma memória sobre uma fantasia." [22]

- "É mesmo muito difícil para mim distinguir entre sonho e realidade ... Posso ter sonhado com alguma coisa, e depois ela acontece, e é esta a duplicação muito estranha da experiência, porque sinto que já tive a experiência. Às vezes, quando acabas de acordar de um sonho [normalmente] ainda ficas um pouco na dúvida, mas em mim isso continua." (Dados não publicados)

• "Uma cena real diurna parece parte de um sonho que tive." [28]

\subsubsection{Interferência do irreal}

A capacidade do sujeito para apreciar ou funcionar na realidade quotidiana é perturbada pela sua preocupação ou distração com um mundo imaginário, delirante ou solipsista (com ou sem compreensão clara da distinção entre o real e o imaginário).

- "Quando as pessoas estavam a falar comigo... em vez de ouvir o que elas estavam realmente a dizer, ouvia qualquer outra coisa que envolvia os meus delírios." (Dados não publicados)

5.7.3 O mundo é experienciado como incoerente, desorientado 
A pessoa pode sentir que o mundo em geral está a perder a sua ordem interna e coerência e se tornou sem sentido e enigmático. Pode estar associado com o sentimento de não ter nenhum ponto estável de orientação ou ponto de vista.

- "Eu... procurava algum ponto fixo, mas não encontrava nenhum ... o muito e o movimento eram demasiado e demasiado rápidos. Toda a gente se afastou de toda a gente. Havia uma corrente como se algo liquefeito estivesse a escorrer para a frente, como se estivesse a evaporar. Tudo era esquemático, fantasmagórico, mesmo eu próprio. "[22] (Considerar também 1.8.3, Perda da integridade ou estrutura espacial e 5.1.2, Intensidade ou substancialidade diminuídas)

• "A realidade é muito complexa. Não consigo encontrar regras básicas. "[39]

\subsubsection{Sobre-consciência perplexa da dimensão tácita}

Aspectos da ação ou interação que normalmente seriam tácitos, emergem do pano de fundo da consciência. O sujeito descreve dificuldades em se envolver no mundo de uma forma natural e pré-reflexiva, em grande parte por causa de uma tendência hiper-reflexiva para se tornar consciente de regras implícitas, pressupostos do senso comum ou aspectos automáticos da ação (por exemplo, ficar fixo ou "bloqueado" na razão pela qual uma ação é feita de uma maneira e não de outra [37]). NB: Pode ser encontrada em conjunto com 3.1, Falta de compreensão social ou sintonia interpessoal.

• "[O paciente] sentia-se paralisado... as suas mãos já não podiam agarrar, pois quem é que lhes dava o direito de pegar em coisas? Os seus pés não conseguiam mais andar, pois quem poderia garantir o chão para os seus passos?" [61]

- "Quanto mais me concentrar na minha respiração, ou sinto que não estou respirar ou que estou a hiperventilar... Sinto que estou constantemente a trabalhar para apenas ser ... Tenho que pensar em fazer tudo." (Dados não publicados)

\subsection{Anomalia na forma de atribuir ou perceber significados}

Há uma qualidade estranha na experiência de percepção do significado dos objetos da consciência, ou na forma como estes inspiram a atribuição de um significado.

5.8.1 Significado imposto ao objeto pelo sujeito 
O sujeito sente-se obrigado a dar um significado especial ou novo a um objeto, muitas vezes de maneira compulsiva. O significado pode ou não ter a ver com a aparência do objeto ou saliência perceptual; pode também estar associado a sentimentos de particularidade estranha.

• "O paciente observou que estava 'forçado a dar as coisas um segundo significado.'" [19]

\subsubsection{Significado inerente ao próprio objeto}

O significado novo e especial aparece de algum modo simultaneamente com a percepção do objeto, experienciado diretamente como uma parte integrante do objeto, sem que o sujeito sinta que este significado é deduzido ou deriva dele. Semelhante à "percepção delirante" [62], embora sem necessariamente ter uma qualidade totalmente delirante.

- "De repente, as coisas parecem significar algo completamente diferente. O paciente vê pessoas de uniforme na rua; são soldados espanhóis. Há outros com uniformes; são soldados turcos. Todo o tipo de soldados estão a ser concentrados aqui. "[14]

- Um paciente "vê incorporada na casca branca [de uma bétula] uma qualidade muito definida, a da inocência" (em vez de a ver como um símbolo de inocência). [19]

\subsubsection{Proliferação de significados do objeto}

Percebido ou pensado. Algo percebido, recordado ou pensado dá origem a uma pletora de pensamentos associados. NB: Se relacionada com a linguagem, pontuar item 4.1.2, Distração por possibilidades semânticas.

- "O meu problema é que eu tenho demasiados pensamentos. O senhor pode pensar em alguma coisa, digamos que naquele cinzeiro, e apenas pensa, ah! sim, isto é para colocar o meu cigarro, mas eu pensaria nisso e logo iria pensar numa dúzia de coisas diferentes relacionadas com isso, ao mesmo tempo." [12]

\subsection{Formas anômalas de significação}

Estas formas anômalas de significado envolvem uma literalidade/concretude ou abstração/generalidade incomuns. O significado percebido é anómalo na sua forma ou estrutura, de modos que implicam uma invulgar literalidade ou concretude, ou então uma exagerada abstração ou generalidade. 
5.9.1 Instanciação física ou literal de significado abstrato

O sujeito considera que pensamentos, sentimentos ou conceitos altamente abstratos (por exemplo, amor, política, verdade, realidade em geral) assumem uma qualidade de certa forma literal, objetificada, até concreta, podendo manifestar-se como objetos (materiais) reconhecíveis na sua experiência do mundo. NB: Se relacionado com a linguagem, ver item 4.8, Experiências anômalas do abstrato e do concreto.

- "Já vi algumas vezes os meus pensamentos flutuando do lado de fora da minha janela como folhas ou flocos de neve." (Dados não publicados)

\subsubsection{Anomalias na classificação}

O sujeito experiencia uma tendência para perceber semelhanças significativas entre objetos ou coisas que não são óbvias para as outras pessoas, ou tem uma inclinação para classificar as coisas de uma maneira invulgar, às vezes hiperabstrata. N.B: Aqui não se trata apenas de oferecer uma definição abstrata (como em 4.8.3, Significados específicos/concretos expressos em terminologia estranhamente abstrata ou geral), mas de sugerir uma classificação ou categorização muito incomum.

- "Os pais são as pessoas que te educam. Qualquer coisa que te eduque pode ser um pai. Os pais podem ser qualquer coisa, material, vegetal ou mineral, que te tenha ensinado algo... Rochas, uma pessoa pode olhar para uma rocha e aprender algo com ela, então ela seria um pai." [22]

• "[As palavras] 'mesa' e 'cadeira' [foram descritas] não como móveis, mas como 'objetos do universo." [22]

\subsection{Intensificação da consciência de padrões ou tendências *}

O sujeito está altamente consciente de padrões ou tendências, que normalmente têm o potencial para parecerem significativos, não acidentais. NB: Pode também envolver 1.4.3, Captação da atenção por detalhes isolados, e 5.14, Humor revelador ou pseudorrevelador.

- "Sei sempre quantos carros vermelhos já vi hoje. Parece que a minha atenção está a demasiado desperta". (Dados não publicados)

\subsection{Sentido anômalo das relações causais}


Uma mudança no sentido normal de causa e efeito ou de padronização de eventos, de tal forma que as coisas parecem estranhamente controladas, predeterminadas ou planeadas. NB: Sobreposições com o Domínio 2: Tempo e eventos, podem ser proeminentes. NB: Para experiências que parecem antitéticas com este item, isto é, quando os acontecimentos ou ações em curso parecem arbitrários ou aleatórios, sem causa ou razão, considerar os itens 2.3.2, Tempo como desarticulado ou fragmentado, 2.4.3, Sentimento de que "qualquer coisa pode acontecer " e 6.2.2 Liberdade conceptual / Qualquer coisa serve.

5.11.1 As ações ou os acontecimentos parecem controlados por uma força ou vontade externa

O sujeito experiencia os acontecimentos como se estivessem sob o controle direto de algum ser externo, força ou subjetividade escondida.

- "... a existência de tal vida [o paciente está a explicar o aparecimento de insetos perante o seu olhar] deve-se às manifestações propositadas do divino poder da vontade ou do divino poder da criação." [57]

5.11.2 As ações ou os acontecimentos parecem predeterminados ou planeados

Tudo parece de algum modo não acidental, ou intencional, sem concessão à possibilidade de aleatoriedade - por vezes associado a apatia em relação ao esforço de realizar qualquer ação (sem declaração clara de força externa ou divina, como no item anterior, embora os dois possam ocorrer em conjunto).

• "Estes "incidentes diabólicos "não são, de certeza, coincidências. As colisões na estrada são obviamente intencionais. O fato de o sabão estar agora sobre a mesa e não estar lá antes é obviamente um insulto." [14]

• "Estes animais [referindo-se a insetos que aparecem num jardim] aparecem sempre em ocasiões definidas e numa ordem definida à minha volta... Não podem ter existido antes e só terem chegado junto de mim acidentalmente." [57]

\subsection{2 "Paranoia" ontológica/Insegurança própria generalizada}

O sujeito tem um sentimento invasivo de estar a ser observado. Este tem uma qualidade nitidamente ontológica ou cósmica, como se estivesse constantemente a ser observado por um indefinível, mas sempre presente (e 
geralmente crítico) outro ou consciência. NB: Este item pode ser semelhante ou ocorrer em conjunto com os itens 3.4.2, Paranoia social ou ansiedade social, ou 6.10, Sentimentos de centralidade, e pode ser pesquisado em conjunto com estes.

• "Pensava que estava a ser vigiado por câmeras de vídeo... Tinha uma terrível sensação de claustrofobia. Sentia-me preso. Era tudo como uma história. "[33]

• "Parece que o universo está centrado em mim." [25] (marcar também 5.14.2, Autoreferenciação)

\subsection{Diminuição da independência ontológica do mundo experienciado/} Subjetivismo

O mundo externo ou parte dele parece não ter existência independente, sendo frequentemente sentido anormalmente dependente ou restrito à perspectiva ou ao estado mental do sujeito.

\subsubsection{Subjetivismo/solipsismo (=EASE 5.3)}

O sujeito sente-se como se os objetos ou pessoas não tivessem existência independente, como se fossem, de certa forma, expressões de ele próprio ou baseassem nele a sua própria existência, ou como se apenas o campo experiencial do próprio sujeito existisse realmente. O sujeito pode sentir como se tivesse criado ou vivenciado tudo o que existe. Isto pode coexistir, ou confundir-se, com um sentido normal da realidade independente do sujeito.

- “Às vezes, um paciente tinha um sentimento passageiro, como se apenas os objetos no seu campo visual existissem. Outras pessoas e lugares não pareciam existir. Ele próprio imediatamente considerava isso um disparate. "[2]

- "Parece que vivi todos os acontecimentos sobre os quais li, ouvi falar ou que sabia de cor." [18]

- "Quando leio um livro ou jornal, penso que as ideias escritas neles são minhas; quando ouço uma música ou um trecho de ópera para o piano, penso que a letra da música ou da ópera expressa os meus sentimentos." [57]

\subsubsection{Duplo registo (Double Bookkeeping)}

O sujeito está ciente de duas ou mais realidades, mas pode distinguir entre o que é real (senso comum prático e realidade social) e outros domínios (delirantes ou 
quase-delirantes) que têm um estatuto menos intersubjetivo, mais privado. $\mathrm{O}$ sujeito pode experienciar algumas coisas de uma forma anômala e idiossincrática, ao mesmo tempo que ainda reconhece e responde aos constrangimentos de senso comum da realidade.

- "Os meus, digamos, delírios estão relacionados apenas com Deus e com o além, não podendo, portanto, influenciar nunca, de forma alguma, o meu comportamento em relação a qualquer assunto mundano..." [57]

• "Muitos das minhas pseudopercepções aberrantes são como são porque, na realidade, estou a percepcioná-las tendo lugar numa realidade paralela que só parcialmente se sobrepõe com o presente." (Dados não publicados)

- "Eu posso sentir com certeza absoluta que o espaço e o tempo (e, portanto, a realidade física) já não existem ou nunca existiram, e ainda assim entender que para poder chegar à consulta de psiquiatria tenho que descer a rua, entrar no comboio e assim...ambas as 'crenças' existem simultaneamente e parecem não colidir, de nenhuma forma, uma com a outra." (Dados não publicados)

\subsubsection{Influência da realidade física (=EASE 5.6)}

O sujeito experiencia formas não naturais de causalidade ligadas à sua própria subjetividade interior. Os objetos ou acontecimentos externos são experienciados como se mudassem de acordo com a experiência ou estado de espírito do sujeito, como se o sujeito estivesse de alguma forma a influenciá-los.

- Ele tinha a impressão de que podia controlar o clima, já que parecia mudar consoante o seu humor. [2]

5.13.4 Pseudomovimentos de objetos e pessoas (=BS C.2.3.7, =EASE 3.9)

"Experiência de pseudomovimentos de objetos ou humanos, especialmente quando o sujeito está, ele próprio, em movimento. Graças a isso, procurará frequentemente evitar o movimento. Ou o sujeito ou o objeto/humano se move em primeiro lugar, ou ambos simultaneamente, e o sujeito sente como se houvesse uma conexão estranha entre os dois" [2] NB:. Em contraste com 3.7.9 Experiência de ser imitado, este subtipo tipicamente não envolve nenhuma sensação de estar sendo intencionalmente mimetizado ou espelhado. No entanto, ambos os subtipos podem ocorrer em conjunto.

• "Só verá uma imagem fixa se não mover a cabeça nem os olhos." [17] 
- "As flores na janela de repente começaram a tremer, a paisagem a mover-se pesadamente. As paredes iam para trás e para a frente." [1]

\subsection{Humor revelador ou pseudorrevelador (apofânico)}

As coisas parecem ter uma qualidade indescritível de distinção, peculiaridade
ou singularidade; o mundo pode ser experienciado como repleto de um sentido
inquietante (uncanny), de misteriosas significâncias. Apesar desses
sentimentos, o sujeito pode ser incapaz de compreender ou especificar
exatamente qual a mudança que ocorreu ou o que poderá significar. NB: Se
combinado com um sentido distinto de iminência, de algo prestes a acontecer,
assinalar também 2.4.1, Antecipação permanente.

\subsubsection{Particularidade uncanny}

Certos detalhes de objetos no mundo aparentam ter uma qualidade de inefável especificidade, peculiaridade, particularidade ou exatidão, que parece significar algo, embora não seja nada que a pessoa consiga identificar.

- "Os sinais estavam tortos, as ruas pareciam suspeitas; tudo acontece tão rapidamente. O cão arranha estranhamente a porta. 'Reparei especialmente' é a observação que esses pacientes fazem constantemente, embora não possam dizer porque repararam tão especialmente nas coisas, nem de que é que suspeitam." [14]

\subsubsection{Auto-referenciação ( BS C.1.17, = EASE 5.1)}

O sujeito experiencia os objetos, acontecimentos quotidianos, ou as outras pessoas, como estando relacionados ou dirigidos a ele de formas incomuns. $\mathrm{O}$ entrevistador deve observar se tal tem probabilidade de ser explicado ou mediado por uma atitude paranoica preexistente, sentimentos de insuficiência, ataque de pânico prévio ou culpa depressiva" [2], uma vez que isso pode alterar a natureza da experiência.

-"Quando estava a tomar café, pensou que as nuvens se assemelhavam a um homem a tomar café." [2]

\subsection{2. a. Significação paranoide *}


O sujeito acredita que algo tem o significado de que outros estão tentando fazerlhe mal de algum modo.

- "Foi como se tudo estivesse a ser feito para me irritar; tudo o que aconteceu em Mannheim aconteceu para me exaustar." [14]

\subsection{2. b. Significação de grandeza}

O sujeito acredita que algo significa que ele próprio possui uma importância superior, como por exemplo ser o "escolhido", "divino", detentor de conhecimento especial ou como sendo audiência privilegiada.

- "Um jovem notou que outros passageiros do comboio ocasionalmente cruzavam as pernas. Sempre que isso acontecia, ele sabia que tudo à sua volta era uma encenação sendo executada em sua honra." [33] (também pontuar 5.1.4, Falsidade)

\subsection{2. c. Significação metafísica}

O sujeito acredita que algo implica uma mudança global no próprio tecido do universo, como a chegada do "fim do mundo", a natureza "ilusória" ou simplesmente "virtual" de tudo ou algum outro significado metafísico. Ele está de alguma forma pessoalmente implicado na mudança ou então é destacado como destinatário da revelação metafísica.

\subsection{2. d. Significação desconhecida/inominável}

Um objeto ou acontecimento tem um significado especial para o sujeito, mas ele é incapaz de dizer qual é.

- "Não são só as coisas que parecem diferentes ou modificadas, parece haver alguma intenção ou motivação por trás dessas mudanças. As coisas parecem ter-se transformado ou terem sido transformadas por uma razão. E de alguma forma - embora eu não consiga descobrir o porquê - isso parece dizer-me inteiramente respeito.” (Dados não publicados)

\subsubsection{Estranheza inespecífica}

A qualidade global do mundo parece modificada de uma forma difícil de especificar, com um tom estranho, peculiar ou suspeito (não sugerindo particularidade estranha ou auto-referencialidade). Frequentemente, o sujeito sentir-se-á compelido a procurar explicações para essas mudanças, como se tudo estivesse envolvido "por uma luz subtil, penetrante e estranhamente incerta." [14] 
• "Algo está a acontecer, por favor diga-me o que é." [14]

• "Algo se está a passar, como se fosse um drama a desenrolar-se." [28]

• "Tudo estava na mesma e, ainda assim, parecia estranho." [47]

\subsection{Experiências quase-místicas}

O sujeito é assaltado por um sentido de unidade ou da mera existência do mundo; pode ter uma qualidade tipo-humor.

\subsubsection{União mística com o mundo *}

O sujeito experiencia um sentimento de profunda união com o resto do mundo.

Este envolve não tanto limites confusos entre o eu e o mundo (ou seja, 1.17, Perda dos limites com o mundo físico), mas antes um profundo sentido, ou mesmo um reconhecimento, de pertencer, ser coextensivo ou idêntico em substância com o mundo externo.

- "Na minha doença mental, eu fui, como pessoa, alargado e esticado para lá de todos os limites razoáveis. Eu era uma parte de tudo, e todo o mundo, às vezes todo o universo, era, de certa forma, uma parte de mim." [22]

\subsubsection{Mera existência}

A preocupação, o deslumbramento ou o foco na simples existência de objetos ou do mundo, sendo a mera existência das coisas sentida ou pensada como muito mais significativa do que a normal significância ou "essência" das coisas.

• "Quando, por exemplo, olhava para uma cadeira ou um jarro... eles tornavam-se 'coisas' e começavam a ter uma vida, a existir... A sua vida consistia unicamente no fato de estarem lá, na sua própria existência." [18]

\subsection{Experiências de fim do mundo}

A sensação de que o mundo está a ser destruído ou a caminhar para um fim catastrófico, ou de que isso está prestes a acontecer. Pode estar associada a certas percepções sensoriais e o sujeito pode, por vezes, acreditar que ele próprio é de alguma forma responsável por esse evento (e pode ser o único a experienciá-lo).

• "Eu ouço o mundo explodir." [29] 
- "Por vezes sinto, claramente e com toda a força, que o mundo vai chegar a um fim, que tudo vai acabar. Mas não porque eu sei como ou o porquê - não tenho nenhuma visão específica - apenas um sentido iminente de um ponto final em todas as coisas." (Dados não publicados)

\subsection{Anomalias do humor ou afeto}

O sujeito experiencia certas anomalias difusas/pervasivas, de natureza semelhante à do humor, na vivência afetiva ou emocional do mundo, podendo ser acompanhadas por dificuldade em perceber, apreender ou expressar emoções normais. Embora muitas vezes descritos em termos de estados internos, geralmente estes tipos de humor também envolvem alterações no sentimento ou na experiência do mundo como um todo. NB: Normalmente, essas experiências parecem distinguir-se das emoções bem direcionadas, dirigidas para o mundo e vinculadas a preocupações humanas normais; em vez disso envolvem uma ansiedade existencial onipresente, estranheza ontológica, etc.

5.17.1 Vazio, entorpecimento, indiferença, falta de resposta espontânea ao mundo * ( BS A.6.3)

O sujeito diz sentir-se vazio e adormecido, sem respostas fortes e espontâneas a eventos de vida ou ao mundo, e incapaz de responder emocionalmente ou de sentir prazer. Pode descrever-se como "calejado" ou como tendo sofrido um "endurecimento dos seus sentimentos" [50], e pode experienciar-se a si mesmo ou ao seu próprio comportamento como profundamente inautêntico. Isto pode ser avaliado negativamente (por exemplo, vergonha, sensação nostálgica de perda), positivamente (sentimento de superioridade) ou neutralmente. Pode estar associado a uma incapacidade de priorizar ou decidir na base da resposta emocional.

- "Tento segurar uma certa emoção, agarrá-la antes que escape. Acho que os outros são mais espontâneas nisto, fazem-no mais livremente e com mais força." [63]

- "Estou sem emoções ou alegria. Estou sempre com o mesmo humor, isto é, num nãohumor, sem oscilações ou mudanças. É um tédio completo. Só vegeto." (Dados não publicados) 
- "A significância emocional imediata e clara parece ter desaparecido e, consequentemente, sinto-me, muitas vezes, confuso e sem saber como responder às pessoas e aos acontecimentos." (Dados não publicados) (também marcar 5.7.3, Mundo é experenciado como incoerente)

- "Estou a começar a sentir-me muito indiferente em relação a tudo porque me estou a tornar num objeto, e os objetos não têm sentimentos." [12]

5.17.2 Sentimentos de bloqueio emocional/afetivo * (no sentido de ser incapaz de expressar)

Em contraste com a dormência emocional do subtipo 1, aqui o sujeito sente-se cheio de uma tensão emocional, afetiva ou uma irritação, que no entanto está bloqueada ou mesmo congelada dentro dele, sem capacidade ou estratégia para expressar essa tensão sentida.

- "Às vezes sinto-me completamente bloqueado, como que paralisado, e não consigo expressar qualquer emoção, negativa ou positiva." (Dados não publicados)

- "Às vezes sinto-me zangado, muito triste ou desesperado, mas não sou capaz de expressá-lo, não consigo comunicá-lo de todo. Limito-me a encarar o meu psiquiatra e sou completamente incapaz de transmitir outra coisa senão uma espécie de branquidão ". (Dados não publicados)

• "É como um bloqueio interno, um bloqueio de sentimentos." [43]

5.17.3 Ansiedade pervasiva e sem nome, com medo da aniquilação * (=EASE 2.14)

O sujeito experiencia uma ansiedade profunda, abrangente ou "ontológica" nos seus encontros com o mundo, ainda que não tenha habitualmente um objeto ou fonte específica para tal e não possa ser prontamente verbalizado ou nomeado. Pode ser acompanhado por um medo de aniquilação, de desaparecer ou de morrer. • "Eu vivo constantemente com medo. Não posso relaxar e não sei porquê." (Dados não publicados)

• "Sob todos os meus medos está o medo da morte, medo de não existir de todo." (Dados não publicados)

5.17.4 Irritação, agitação, raiva básicas (disforia não-emocional)* 
O sujeito experiencia uma irritação e inquietação profundas e inexprimíveis nas suas interações com o mundo, que não podem ser adequadamente comunicadas. Às vezes experienciada como raiva profunda ou angústia.

• "Desde que me lembro, senti uma irritação profunda: ubíqua, poderosa e irresistível." (Dados não publicados)

- "A inquietação, bem fundo dentro de mim, provocou um enorme fosso entre mim e as outras pessoas. Se ao menos eu pudesse sentir uma emoção como amor, ódio ou qualquer coisa! Porque as emoções significam que tu és parte de uma sociedade, com esta inquietação eu não sou." (Dados não publicados)

- "...uma espécie de inquietação interna ou irritação mental... quase fisicamente insuportável, [mas] definitivamente na minha mente, uma coisa mental." (Dados não publicados)

\subsubsection{Euforia sem objeto}

O sujeito experiencia um sentimento de júbilo ou euforia não-emocionais (não dirigidos a alguém ou algo em particular). Em contraste com a maioria dos casos de euforia maníaca, este estado de humor normalmente tem uma qualidade fria, individual ou serena (não orientado para a ação ou frenético).

- "Tive algumas experiências estranhas como viajar no tempo e voar para o planeta Marte em que a sensação era diferente de tudo o que já tinha experimentado... como de beleza profunda do universo, e também, nesses momentos, a sensação de que entendia as coisas de uma forma mais profunda. "(dados não publicados)

5.17.6 Desespero, desmoralização, desesperança * ( B A.6.1)

O sujeito fica desesperado ou desmoralizado nas suas relações com o mundo. Isto pode dever-se ao sentimento de incapacidade de interagir com os outros e levar algum tipo de vida normal, e pode envolver sentimentos de encarceramento, desesperança, ou a procura de refúgio na ideia de suicídio.

- "As minhas aflições preenchem o lugar que estava destinado à partilha de amor. Estou a chorar de desespero." [64]

- "O mundo é um lugar frio e hostil em que estamos condenados à solidão, estranhamento e, finalmente, à morte." [65]

5.17.7 Anomalias na constância do humor* 


\subsection{7 a. O humor ou emoção é anormalmente persistente *}

$\mathrm{O}$ humor ou as emoções são vivenciados como atrasados em relação aos pensamentos ou circunstâncias.

- "Tem havido alturas em que as minhas emoções... ficam presas, mesmo que eu tenha mudado e esteja numa nova situação... De alguma forma, o humor ainda está lá, de uma forma estranha... Apenas fica lá, uma emoção sem nada realmente ligado a ela." (Dados não publicados)

\subsection{7 b. O humor ou emoção é anormalmente lábil *}

O humor é propenso a alterações bruscas sem razão ou transição. O sujeito "muitas vezes salta de um afeto para outro", movendo-se por exemplo, num instante, de um estado de intensa agitação "para um humor exageradamente erótico e feliz, apenas para se tornar choroso e triste alguns minutos mais tarde." [50]

\subsubsection{Incongruência do humor e emoções}

\subsection{8 a. Humor ou emoção inapropriados à situação}

De alguma forma o humor "não se encaixa com" os pensamentos ou com a situação atuais (à exceção dos que envolvem indiferença, que são pesquisados no subtipo 1); por exemplo, tristeza inapropriada quando confrontado com um acontecimento feliz, ou vice-versa.

\subsection{8 b. Humores e emoções são mutuamente contraditórios}

No que é sentido como uma forma incongruente e muitas vezes desconcertante: "ambivalência afetiva" [50], uma convivência ou simultaneidade de sentimentos ou emoções opostas e/ou em conflito, presumivelmente distintos da ambivalência normal de sentimentos.

• "Eu experiencio opostos simultaneamente. Como se eu lesse a palavra "branco" e tivesse que pensar preto. Mas também é assim com os sentimentos, portanto posso sentir-me excitado e enojado, interessado e desinteressado, esse tipo de coisas..." (Dados não publicados)

\section{Orientação existencial}

Descrição geral: Os 11 itens no Domínio 6 referem-se a uma orientação anormal em 
curso ou a uma "reorientação fundamental" da "perspectiva metafísica geral e/ou hierarquia de valores, projetos e interesses da pessoa" [2]. As anomalias em questão manifestam-se como atitudes, opiniões ou orientações existenciais. Os itens do domínio 5 da EASE estão incluídos aqui sempre que não envolvam claramente impressões gerais primárias referentes à visão do mundo pelo sujeito, mas atitudes ou interpretações relativas ao mundo ou à relação individual com ele. (Estes podem certamente sobreporse; ver, por exemplo, item 6.4, Certeza Absoluta; ver também o subtipo 6.2.2, Liberdade conceptual/ Qualquer coisa serve). As questões neste domínio podem interceptar alguns aspectos previamente discutidos na entrevista. No entanto, caso o entrevistador tenha dúvidas sobre a presença ou ausência de um fenômeno do Domínio 6, este deverá ser explicitamente inquirido.

Poderá ser útil obter mais informação realizando questões que garantam a continuidade sempre que o paciente confirmar um item de "orientação existencial". (NB: Ainda que relevante ao longo do EAWE, este aspecto é particularmente destacado nesta secção). Estas questões podem incluir:

Pode dizer desde quando, e quão consistentemente, teve esta sensação de... (entrevistador especifica a sensação/atitude em questão)?

Tem essas sensações desde que se consegue lembrar? Constantemente ou de modo intermitente?

As sensações começaram apenas depois de ter começado a vivenciar outras experiências anormais envolvendo a percepção, o pensamento ou os sentimentos - ou, talvez, ocorrem ... apenas na presença de outras experiências anormais?

...apenas depois de ter começado a tomar medicação psiquiátrica ou outras classes de fármacos?

... depois de alguma experiência altamente marcante ou eventualmente difícil, ou outra alteração nas circunstâncias da sua vida?

\subsection{Rejeição da sociedade ou da convenção}

O sujeito rejeita ou recusa valores sociais geralmente aceites ou a participação numa sociedade humana normal, escolhendo viver de acordo com os seus próprios valores idiossincráticos ou tipos de conduta. Isso é habitualmente experienciado como tendo um grande elemento voluntário; não 
se deve primariamente a alterações do humor (elação ou humor deprimido), ou baixa autoestima. Pode estar associado a sentimentos de incompetência social ou medo de perder a identidade individual ou originalidade se se identificar demasiado com os outros ou se conformar com a sociedade.

6.1.1 Rejeição da sociedade humana.

O sujeito rejeita conscientemente a sociedade humana normal, podendo em vez disso viver como solitário ou desajustado social.

- "O que detesto mais do que qualquer outra coisa é ser persuadido por outros." [41]

- "Estou mudado. Estou a tornar-me mais humano. Isto vai arruinar-me o cérebro? Toda esta humanidade está a desorganizar as minhas regras de funcionamento. Está a poluirme." [41]

- "Não consigo alcançá-los (às outras pessoas), mas também não os quero alcançar." [41]

\subsubsection{Antagonomia}

$O$ sujeito age de um modo que contraria as normas sociais, não apenas desconsiderando regras e valores, mas agindo de um modo que se opõe a eles diretamente, muitas vezes com repugnância, cepticismo, ou desdém em relação a convenções ou ao que é tipicamente um dado adquirido.

- “A minha aversão ao senso comum é mais forte do que o meu instinto de sobrevivência. É por isso que digo que ser contra o senso comum é simultaneamente um presente e um castigo." [41]

\subsubsection{Idionomia}

O sujeito manifesta um sentimento de ser radicalmente único ou excepcional no que toca à sua forma de ser em relação ao senso comum, assim opta por ser fiel à sua própria individualidade ou adquirindo uma postura excêntrica.

- "A loucura é necessária para que a inteligência humana chegue a níveis superiores." [41]

- "Doutor, tenho uma missão a cumprir. Antes de mais, construir o meu país - a Somália - e depois, em conjunto com o meu irmão, construir um mundo mais habitável e fraterno. Apercebi-me de que há uma nova cultura no mundo, o mundo de amanhã, o da irmandade.” [41] (Também pontuar 6.5.2, Dever messiânico) 
- "Tenho a invenção na minha cabeça. O que tenho não é uma doença, mas uma experiência. Eu fui escolhido para isto. Algo extremamente importante.” [41] (Também pontuar 6.5.2: Dever messiânico)

\subsection{Extrema indiferença ou abertura a experiências}

O sujeito demonstra uma muito improvável aceitação ou abertura (em relação a valores ou ideias) a uma variedade de possibilidades mais ampla que o normal, sugerindo um desprendimento das preocupações habituais ou senso comum.

6.2.1 Atitude de indiferença, insatisfação ou despreocupação

O sujeito relata uma atitude ou postura de extrema indiferença no que toca à experiência; nada realmente importa ("indiferença esquizofrênica" [37]; "jem'en-fichisme" [estar-se a marimbar; não dar importância] com uma "indiferença calosa" [50]). A indiferença parece ter uma qualidade casual ou isolada, distinta da incapacidade do deprimido em preocupar-se, ou do entusiasmo indiscriminado da mania.

- "Eu sou um existencialista, tudo é o mesmo para mim, não necessito de nenhum diploma. Os existencialistas são pessoas para quem tudo é igual.” [37]

\subsubsection{Liberdade conceptual/ Qualquer coisa serve}

O sujeito sente-se como se fosse mais aberto a possibilidades de interpretação ou compreensão do que os outros, frequentemente de modos que podem interromper a ação convencional, a tomada de decisões, ou a compreensão conceptual. NB: Em contraste com 2.4.3, Sentimento de que "qualquer coisa pode acontecer," o foco aqui está nas possibilidades de interpretação, não na imprevisibilidade do fluxo temporal (ainda que os dois possam coocorrer). NB: Considere-se também 6.3, Descrença pervasiva, cepticismo, ou curiosidade em relação ao óbvio/dado adquirido. Se acompanhada pela experiência ou significados proliferativos, considere-se também o score 5.8.3 Proliferação de significados do objeto.

- "Se não acreditar mais na gravidade, não significa que falhe a antecipar algo ao não esperar que uma maçã caia da árvore, mas que simplesmente penso que a maçã poderia 
tão facilmente flutuar apenas, ou voar, não tendo, portanto, qualquer razão para antecipar a sua queda." (Dados não publicados)

- "[Um] paciente tinha dificuldade em chegar ao que é habitualmente considerada a "resposta correta [num teste de organização de imagens] porque, como disse, 'qualquer ordem faria sentido'.” [22]

-Um paciente "via coisas com diferentes graus de probabilidade como se fossem todas igualmente prováveis", uma vez que é possível que os arquivos históricos sejam adulterados (mesmo se altamente improvável em larga escala), insistindo que ninguém poderia confiar de todo num relato histórico. [22] (Também registrar 6.3, Descrença pervasiva, cepticismo, ou curiosidade em relação ao óbvio/dado adquirido.)

\subsection{Descrença pervasiva, cepticismo, ou curiosidade em relação ao óbvio/dado adquirido ( EASE 2.12)}

Descrença persistente e inevitável por, ou curiosidade desconfiada sobre, coisas que para a maioria das pessoas são dados adquiridos, considerados óbvios e verdadeiros (por exemplo, convenções sociais, premissas fundamentais sobre o mundo - tal como a existência da gravidade). Pode estar ligada a outros padrões de pensamento e comportamento, tais como a necessidade de perceber a "verdadeira" natureza do tempo, da vida, ou do universo. NB: Considere-se também 6.2.2, Liberdade conceptual/ Qualquer coisa serve.

- "Pergunto-me por vezes onde acaba este globo. Olho em volta e pergunto-me se poderei alcançar esse fim.” (Dados não publicados).

- "Por vezes penso sobre de onde veio a primeira palavra. Quem surgiu com as primeiras palavras, e de onde veio. Não compreendo como temos sementes, percebe? De onde vêm as sementes?" (Dados não publicados)

- "Duvido de tudo e de todos. Às vezes até duvido que os meus pais são mesmo meus pais, ou que a Ljubljana é a capital da Eslovênia.” (Dados não publicados)

\subsection{Certeza Absoluta}

O paciente experiencia uma sensação de total certeza sobre interpretações anômalas do mundo, como se tudo fosse já tão claro e certo como $2+2=4$ : quaisquer provas são, portanto, desnecessárias e a refutação inimaginável. O sujeito expressa "uma convicção extraordinária, com uma certeza subjetiva 
incomparável, [e] impenetrabilidade a outras experiências [ou] contraargumentos persuasivos..." [14]

• "Bem, isto é como é; Não tenho dúvidas sobre isso, eu sei que assim é." "Tudo é tão seguramente certo que por muito que mostrem o contrário não me farão duvidar." [14]

- "As verdades que encontrei apresentavam-se imediata e diretamente com certeza absoluta." [66]

\subsection{Sensação de ser especial ou superior}

O sujeito experiencia uma sensação de ser extremamente especial, tipicamente por possuir conhecimento, insight ou capacidade superior elou por ter um dever especial ou um papel a desempenhar no mundo ou universo.

6.5.1 Sentimento de possuir uma consciência extraordinária* (= EASE 5.4) (em dimensões ocultas da realidade ou da mente, com a sensação de ter poderes especiais criativos ou intelectuais)

Estas capacidades podem variar desde o meramente notável ao verdadeiramente sobrenatural, e podem incluir, por exemplo, o sentir uma capacidade extraordinária para compreender ou criar poesia ou conceitos matemáticos, ou ter revelações em relação à essência do tempo, da morte, ou do universo.

- "Cheguei infinitamente mais perto da verdade do que os seres humanos que não receberam a revelação divina." [57]

- "Eu sabia que me tinham sido dados poderes por Deus para penetrar o sentido profundo da realidade." [43]

\subsubsection{Dever messiânico *}

O sujeito possui um sentido de dever extraordinário em relação aos outros, como se sentisse ser ele mesmo um messias ou um gênio criativo, incumbido de ajudar ou salvar outras pessoas, o planeta, a vida extraterrestre, etc.

- “Tenho uma missão a cumprir. Salvar o mundo da autodestruição." (Dados não publicados)

6.5.3 Grandiosidade intelectual/espiritual (= EASE 5.8)

(com comparação preconceituosa) 
O sujeito exibe um marcado "sentido de superioridade sobre os seus companheiros humanos, tipicamente associado a sensações de posse de insight ou capacidades extraordinárias." [2] Outros poderão ser vistos como menos inteligentes ou evoluídos, mais limitados ou superficiais - como se houvesse uma divisão distinta no que toca à própria capacidade de percepção consciente.

- Um paciente disse que "chegou a uma compreensão da mente mais completa que, e perdão por aquilo que poderá parecer-lhe grandiosidade minha, mais completa do que a de qualquer outro na história da humanidade"; a maioria dos outros seres humanos pareciam puramente mentes "mecânicas": "máquinas orgânicas" ou "vegetais mentais" [22] (Também marcar/pontuar 3.9.3, As pessoas parecem mecânicas)

\subsection{Responsabilidade ou culpa impossíveis*}

Sentimentos de culpa ou um sentido de responsabilidade desmesurado em relação a algo impossível de ter sido feito ou causado pela pessoa - tal como ter causado uma guerra, algum acidente trágico que apareça nas notícias, ou ter prejudicado outros de algum modo impossível.

- "Contei ao primeiro psiquiatra que visitei que me sentia responsável pela Guerra do Golfo, e que me culpava por coisas com que nada tinha a ver". (Dados não publicados)

\subsection{Sentimento de perda de liberdade ou individualidade}

O sujeito sente-se como se o próprio fosse um autômato sem liberdade ou originalidade, como se impelido e completamente determinado por forças externas. NB: Ao contrário de 5.11.1, As ações ou os acontecimentos parecem controlados por uma força ou vontade externa, e 5.11.2, As ações ou os acontecimentos parecem predeterminados ou planeados, o foco aqui é menos centrado no mundo como oposição ao self.

- Uma paciente declarou que "tinha estado sob influência de uma máquina eléctrica... sendo manipulada por alguém de um certo modo, em que tudo o que lhe ocorre [à máquina] também lhe acontece a ela.” [22]

- "Sou monitorizado para reagir como esperado, e isso acontece tão rapidamente que eu, mesmo que queira, sou incapaz de me conter.” [22]

\subsection{Preferência pelo abstrato, intelectualismo elou regras autônomas}


$\mathrm{O}$ sujeito sente-se impelido a seguir um conjunto estrito de regras e valores que enfatizam a racionalidade, uma atitude intelectual, princípios abstratos ou idealísticos, um desejo compulsivo por seguir "regras" ou "leis" idiossincráticas. Frequentemente envolve uma ideologia intelectual, espiritual, moralista ou utópica, separada de realidades concretas, corporais ou contextuais da vida social e prática.

- "[Um paciente] adopta um sistema pedagógico cujo princípio se altera uma vez por semana: alterna entre uma rigorosa disciplina militar e um princípio de indulgência absoluta, ou 'princípio liberal de amabilidade'.” [67]

- Uma mulher deixou de usar qualquer faca ou tesoura (mesmo para cortar vegetais ou abrir uma embalagem) por acreditar que estavam vinculadas com a circuncisão. (Dados não publicados) (Considerar também 5.8.2, Significado inerente ao próprio objeto)

\subsection{Mudança existencial ou intelectual* (= EASE 5.7)}

Preocupação nova ou pouco comum com temas existenciais, metafísicos, religiosos, filosóficos ou psicológicos. Temas frequentemente relatados: fenômenos sobrenaturais; religião (especialmente não-standard); experiência mística; filosofia; temas transcendentais; meditação; psicologia; rituais ancestrais; símbolos; reencarnação; vida depois da morte; luta entre o bom e o mal; paz e comunicação universal; sentido da existência; destino da humanidade; salvação; ciência não convencional ou ideias relacionadas sobre saúde e nutrição. [2]

- "Era absorvido pelas ideias e interesses novos que ultrapassavam gradualmente a minha vida e pensamento; deixaram uma marca em toda a minha vida." [2]

- "Estou extremamente ocupado com pensamentos sobre como ser suficientemente bom." [2]

\subsection{Sentimento de centralidade (= EASE 5.2)}

Sentimentos transitórios ou persistentes sobre ser o centro do universo - que parece ser organizado em torno, controlado por, ou dependente do sujeito. NB: Este item difere dos sentimentos mais comuns de ser observado, admirado ou criticado por outras pessoas, como presente no item 3.4.2, Sentimentos de paranoia social ou ansiedade social*; tal como o 5.1.2, 


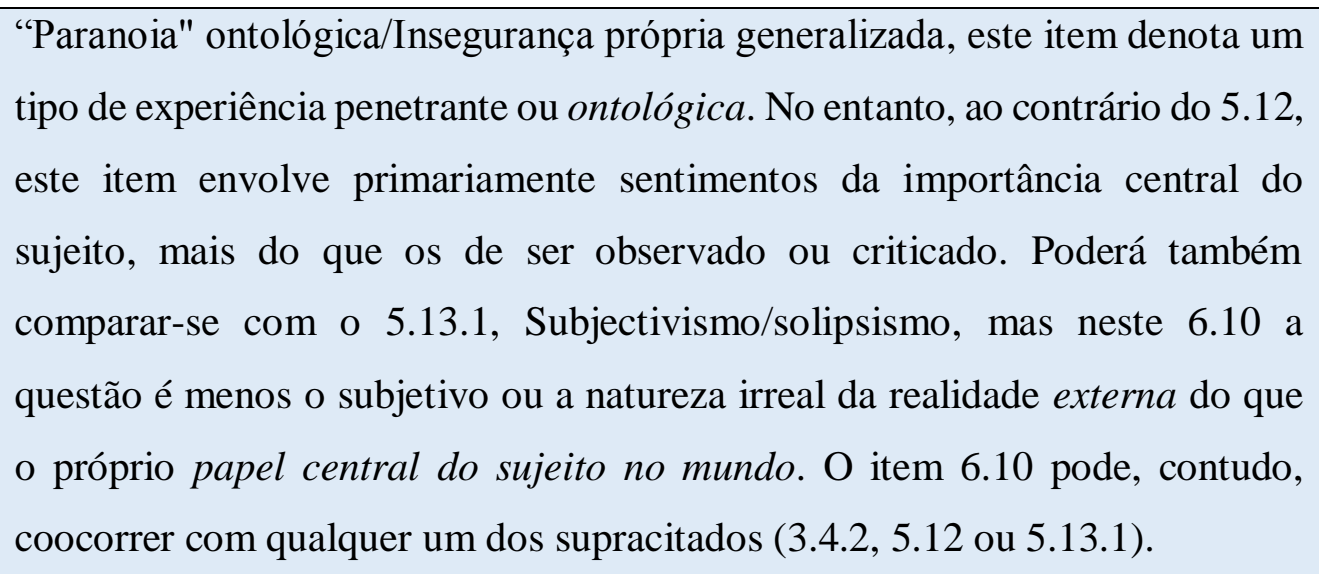

- O paciente pode dizer "Tenho a sensação de que tudo gira à minha volta. Sou como um pequeno deus, o tempo é controlado por mim.” [36]

- "Numa festa, tudo parecia originar-se a partir dele ou depender dele." [2]

- "Sinto como se fosse o ego-centro da sociedade." [43]

- "Eu me transformei, de alguma forma, no único ser humano para Deus, ou simplesmente o ser humano em torno de quem tudo gira." [57, 69]

\subsection{Descentralização do self em relação ao universo}

O sujeito duvida da natureza do que é real ou do seu mundo imediato, acreditando que ele, de algum modo, existe fora ou separado de outra realidade "mais verdadeira". Pode sentir como se ele, ou aquilo que o envolve, fosse uma ficção criada pela imaginação de alguém ou uma personagem numa cena do livro de outra pessoa.

- "Isto está mesmo a acontecer? Isto é realmente o Universo, ou é só algum tipo de ameba numa caixa de Petri dentro de um Universo maior?” (Dados não publicados) 
Referências Bibliográficas

1. Gross G, Huber G, Klosterkötter J, Linz M: Bonn Scale for the Assessment of Basic Symptoms. Aachen, Shaker, 2008.

2. Parnas J, Møller P, Kircher T, Thalbitzer J, Jansson L, Handest P, Zahavi D: EASE: Examination of Anomalous Self-Experience. Psychopathology 2005; 38: 236-258.

3. Sass L, Pienkos E, Fuchs T: Other worlds: introduction to the special issue on the EAWE: Examination of Anomalous World Experience. Psychopathology 2017, DOI $10.1159 / 000456215$.

4. Merleau-Ponty M: Phenomenology of Perception. London, Routledge, 2012.

5. Sass L, Parnas J: Schizophrenia, consciousness, and the self. Schizophr Bull 2003; 29: $427-444$.

6. Husserl E: The Phenomenology of Internal Time Consciousness. Bloomington, Indiana University Press, 1964.

7. James W: Principles of Psychology. Cambridge, Harvard University Press, 1890.

8. Heidegger M: Being and Time. New York, Harper \& Row, 1962.

9. Husserl E: Cartesian Meditations. Dordrecht, Kluwer, 1950.

10. Koehler K: First rank symptoms of schizophrenia: questions concerning clinical boundaries. Br J Psychiatry 1979; 134:236-248.

11. Conerty J, Skodlar B, Pienkos E, Byrom G, Sass L: The Examination of Anomalous World Experience in schizophrenia and other disorders: a report on reliability. Psychopathology 2017, DOI 10.1159/000454865.

12. McGhie A, Chapman J: Disorders of attention and perception in early schizophrenia. Br J Med Psychol 1961;34:103-116.

13. Cutting J: The Right Cerebral Hemisphere and Psychiatric Disorders. New York, Oxford University Press, 1990.

14. Jaspers K: General Psychopathology. Chicago, University of Chicago Press, 1963. 15. Cutting J: Principles of Psychopathology. Oxford, Oxford University Press, 1997. 16. Lenzenweger M: Schizotypy and Schizophrenia: The View from Experimental Psychopathology. New York, Guilford, 2011.

17. Chapman J: The early symptoms of schizophrenia. Br J Psychiatry 1966; 112:225251.

18. Sechehaye M: Autobiography of a Schizophrenic Girl. New York, Penguin, 1962. 
19. Matussek P: Studies in delusional perception; in Cutting J, Shepherd M (eds): The Clinical Roots of the Schizophrenia Concept. Cambridge, Cambridge University Press, 1987, pp 89-103.

20. Wagner P, Spiro CS: Divided Minds: Twin Sisters and Their Journey through Schizophrenia. New York, St. Martin's Press, 2008.

21. Stanghellini G, Rosfort R: Emotions and Personhood: Exploring Fragility, Making Sense of Vulnerability. Oxford, Oxford University Press, 2013.

22. Sass L: Madness and Modernism: Insanity in the Light of Modern Art, Literature, and Thought. New York, Basic Books, 1992; rev ed: Oxford, Oxford University Press, 2017.

23. Jones N, Luhrmann T: Beyond the sensory: findings from an in-depth analysis of the phenomenology of "auditory hallucinations" in schizophrenia. Psychosis 2016;8:191-202.

24. Hamilton M (ed): Fish's Schizophrenia, ed 3. Bristol, Wright, 1984.

25. Payne R: Night's end. Schizophr Bull 2012; 38: 899-901.

26. Stanghellini G: Schizophrenia and the sixth sense; in Chung M, Fulford K, Graham G (eds): Reconceiving Schizophrenia. Oxford, Oxford University Press, 2007, pp $129-150$.

27. Cutting J, Silzer H: Psychopathology of time in brain disease and schizophrenia. Behav Neurol 1990;3:197-215.

28. Stanghellini G, Ballerini M, Presenza S, Mancini M, Raballo A, Blasi S, Cutting J: Psychopathology of lived time: abnormal time experience in persons with schizophrenia. Schizophr Bull 2016; 42:45-55.

29. Minkowski E: Lived Time. Evanston, Northwestern University Press, 1933/1970.

30. Silverstein SM: Fragmentary phenomena scale, unpublished.

31. Fuchs T: The temporal structure of intentionality and its disturbance in schizophrenia. Psychopathology 2007; 40:229-235.

32. Fuchs T: Temporality and psychopathology. Phenomenol Cogn Sci 2013;12:75104.

33. Cutting J: The Psychology of Schizophrenia. Oxford, Churchill Livingstone, 1985.

34. Northoff G, Stanghellini G: How to link brain and experience? Spatiotemporal psychopathology of the lived body. Front Hum Neurosci 2016;10:76. 
35. Kimura B: Écrits de psychopathologie phénoménologique. Paris, Presses

Universitaires de France, 1992.

36. Conrad K: Die beginnende Schizophrenie: Versuch einer Gestaltanalyse des Wahns. Stuttgart, Thieme, 1958.

37. Blankenburg W: Der Verlust der natürlichen Selbstverständlichkeit. Ein Beitrag zur Psychopathologie symptomarmer Schizophrenien. Stuttgart, Enke, 1971.

38. Minkowski E: La schizophré nie. Paris, Payot, 1927.

39. Stanghellini G, Ballerini M: What is it like to be a person with schizophrenia in the social world? A first-person perspective study on schizophrenic dissociality. Part 2: methodological issues and empirical findings. Psychopathology 2011; 44:183-192.

40. Laing RD: The Divided Self. New York, Penguin, 1965.

41. Stanghellini G, Ballerini M: Values in persons with schizophrenia. Schizophr Bull 2007;33: 131-141.

42. Adam: Experiencing suspicious thoughts and paranoia: an account. Schizophr Bull 2011; 37:656-658.

43. Stanghellini G, Ballerini M, Lysaker P: Autism Rating Scale. J Psychopathol 2014; 20:273-285.

44. Rossi Monti M, Stanghellini G: Influencing and being influenced: the other side of “bizarre delusions.” 1. Analysis of the concept. Psychopathology 1993;26:159-164.

45. Landis C: Varieties of Psychopathological Experience. New York, Holt, Rinehart \& Winston, 1964.

46. Cutting J: The Living, the Dead, and the Never-Alive. Hove, Forest Publishing, 2002.

47. Reed G: The Psychology of Anomalous Experience: A Cognitive Approach. London, Hutchinson, 1972.

48. Sass L: Delusion and double bookkeeping: in Fuchs T, Breyer T, Mundt C (eds):

Karl Jaspers' Philosophy and Psychopathology. New York/Heidelberg, Springer, 2014, pp. 125-147.

49. Anonymous: Language games, paranoia, and psychosis. Schizophr Bull, 2011; 37:1099-1100.

50. Bleuler E: Dementia Praecox or the Group of Schizophrenias. New York, International Universities Press, 1950. 
51. Stanghellini G: The Cratylus effect: a case study in semantic deconstruction. J Psychopathol 2016;22:80-89.

52. Ey H: Schizophrénie: Études Cliniques et Psychopathologiques. Paris, Synthelabo, 1996.

53. Sass L, Pienkos E: Beyond words: linguistic experience in melancholia, mania, and schizophrenia. Phenom Cogn Sci 2015; 14: 475-495.

54. Binswanger L: Extravagence, perverseness, manneristic behavior, and schizophrenia; in Cutting J, Shepherd M (eds): The Clinical Roots of the Schizophrenia Concept. Cambridge, Cambridge University Press, 1987, pp 83-88.

55. Møller P, Husby R: The initial prodrome in schizophrenia: searching for naturalistic core dimension of experience and behavior. Schizophr Bull 2000; 26:217-236.

56. Rosser R: The psychopathology of feeling and thinking in a schizophrenic. Int $\mathbf{J}$ Psychoanal 1979; 60:177-188.

57. Schreber DP: Memoirs of My Nervous Illness. London, Dawson, 1955.

58. Brett C: Psychotic and mystical states of being: connections and distinctions. Philos Psychiatry Psychol 2002;9:321-341.

59. Madeira L, Bonoldi I, Rocchetti M, et al: Prevalence and implications of Truman symptoms in subjects at ultra high risk for psychosis. Psychiatry Res 2016; 238:270276.

60. Minkowski E: The essential disorder underlying schizophrenia and schizophrenic thought; in Cutting J, Shepherd M (eds): The Clinical Roots of the Schizophrenia Concept. Cambridge, Cambridge University Press, 1987, pp 188-212.

61. Stanghellini G: Vulnerability to schizophrenia and lack of common sense. Schizophr Bull 2000; 26:775-787.

62. Schneider K: Clinical Psychopathology. New York, Grune \& Stratton, 1959.

63. Vodusek V, Parnas J, Tomori M, Skodlar B: The phenomenology of emotion experience in first-episode psychosis. Psychopathology 2014; 47:252-260.

64. Bouricius JK: Negative symptoms and emotions in schizophrenia. Schizophr Bull 1989; 15:201-208.

65. Henriksen M, Skodlar B, Sass L, Parnas J: Autism and perplexity: a qualitative and theoretical study of basic subjective experiences in schizophrenia. Psychopathology 2010;43: 357-368. 
66. Müller-Suur H: Das Gewissheitsproblem beim schizophrenen und beim paranoischen Wahnerleben. Fortschr Neurol Psychiatr 1950; 18: 44-51.

67. Kaplan B (ed): The Inner World of Mental Illness. New York, Harper \& Row, 1964.

68. Urfer A: Phenomenology and psychopathology of schizophrenia: the views of Eugene Minkowski. Philos Psychiatry Psychol 2001; 8: 279-289.

69. Sass L: The Paradoxes of Delusion: Wittgenstein, Schreber, and the Schizophrenic Mind. Ithaca, Cornell University Press, 1994. 